Aus der Abteilung für Neuroradiologie der Universität Würzburg

Direktor: Prof. Dr. L. Solymosi

\title{
Differential imaging characteristics and dissemination potential of pilomyxoid astrocytomas versus pilocytic astrocytomas
}

\author{
Inaugural - Dissertation \\ zur Erlangung der Doktorwürde \\ der Medizinischen Fakultät \\ der
}

Julius-Maximilians-Universität Würzburg

\author{
vorgelegt von \\ Bálint Alkonyi \\ aus Pécs, Ungarn
}

Würzburg, November 2014 
Referent: Prof. Dr. Monika Warmuth-Metz

Koreferent: Prof. Dr. Matthias Eyrich

Dekan: Prof. Dr. Matthias Frosch

Tag der mündlichen Prüfung: 15.07.2015

Der Promovend ist Arzt. 
Für

meine Eltern und meine Ehefrau

The science of today is the technology of tomorrow.

(Edward Teller, American-Hungarian physicist) 


\section{TABLE OF CONTENTS}

1. Introduction 1

1.1 Pilocytic astrocytoma $\quad 1$

1.2 Pilomyxoid astrocytoma 3

1.3 Computed tomography and magnetic resonance imaging 5

1.4 Imaging of pilocytic astrocytoma and pilomyxoid astrocytoma $\quad 7$

$\begin{array}{lr}1.5 \text { Aims of the study } & 8\end{array}$

2. Material and Methods $\quad 9$

$\begin{array}{ll}2.1 \text { Study population } & 9\end{array}$

$\begin{array}{ll}2.2 \text { Image analysis } & 10\end{array}$

$\begin{array}{ll}2.3 \text { Statistical analysis } & 11\end{array}$

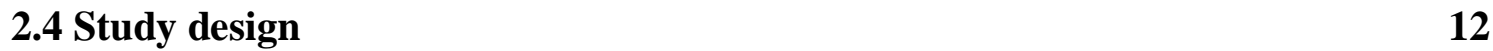

$\begin{array}{ll}\text { 3. Results } & 13\end{array}$

4. Discussion $\quad 23$

$\begin{array}{ll}\text { 5. Summary } & 30\end{array}$

$\begin{array}{ll}\text { 6. Zusammenfassung } & 32\end{array}$

$\begin{array}{ll}\text { 7. References } & 33\end{array}$

$\begin{array}{ll}\text { 8. Appendix } & 39\end{array}$ 
9. Abbreviations $\quad 45$

10. Danksagung

not numbered

11. Lebenslauf

not numbered 


\section{INTRODUCTION}

\subsection{Pilocytic astrocytoma}

Low-grade gliomas (LGGs) of the childhood are the most common pediatric brain tumors and represent a spectrum of diseases. Among low-grade gliomas pilocytic astrocytomas (PAs) or juvenile pilocytic astrocytomas are the most common primary brain tumors of the childhood and the most common cerebellar neoplasms in the pediatric population (Burger et al., 2000b). They are grade I astrocytic tumors according to the World Health Organization (WHO) classification (Louis et al., 2007). Accordingly, they are slow growing, have a noteworthy benign biologic behavior and an overall good prognosis. 75\% of the PAs occur in the first two decades of life, typically late in the first decade (Wallner et al., 1988; Burger et al., 2000a). The most common location of PAs is the cerebellum (60\%). Furthermore, a substantial proportion of PAs arise in the visual pathway (optic nerve, optic chiasm) or in the region of the hypothalamus-thalamus. Other less common sites include the brainstem, velum interpositum, cerebral hemispheres and the spinal cord (Koeller et al., 2004). No gender predisposition has been recognized. Clinical presentation depends on the tumor location. As most pediatric brain tumors they commonly present with symptoms of increased intracranial pressure or parenchymal compression, including failure to thrive (lack of appropriate weight gain), developmental delay, impaired consciousness, nausea, vomiting, irritability, headache, etc. In case of a cerebellar tumor location, gait abnormalities, ataxia, dysmetria and nystagmus belong to the common clinical signs (Gol et al., 1959; Pencalet et al., 1999). Chiasmatic-hypothalamic PAs typically lead to visual loss or visualfield deficit, hypothalamic-pituitary dysfunction, as well as symptoms secondary to hydrocephalus (Burger et al., 2000b). Occasionally hypothalamic PAs may cause the so-called diencephalic syndrome (Rodriguez et al., 1990; Poussaint et al., 1997). The diencephalic syndrome is characterized by profound emaciation with absence of cutaneous adipose tissue despite normal caloric intake. Other features of this syndrome include locomotor overactivity, hyperalertness, hyperkinesis, and euphoria (Russel, 1951). It is most often associated with a hypothalamic/chiasmatic astrocytoma; however, it has also been described in association with other lesions, such as midline cerebellar astrocytoma (Udvarhelyi, 1966). 
Histologically PAs are characterized by the `biphasic` pattern with alternating compact, densely cellular piloid tissue and loose glial tissue with vacuoles and microcysts (Burger et al., 2002). The term pilocytic refers to the elongated bipolar cells with hair-like processes, a highly distinctive feature of PAs. Further features include the abundance of Rosenthal fibers and the presence of eosinophil granular bodies which are degenerative products of astrocyte formation. Mitotic figures are scarce and microcalcifications are uncommon. Although many PAs appear macroscopically well circumscribed, they may infiltrate the adjacent brain tissue; this pheomenon is more common in case of tumors of the visual pathway (Coakley et al., 1995; Burger et al., 2000b). PAs are highly vascular and are characterized by markedly hyalinized and glomeruloid vessels.

Neurofibromatosis type 1 (NF1) or von Recklinghausen disease is a multisystem autosomal dominant inherited neurocutaneous disorder (the most common phakomatosis) predisposing to increased incidence of several tumors (Mulvihill et al., 1990; Williams et al., 2009). PA is strongly associated with NF1. PAs are the most common tumor in this population (Rodriguez et al., 2008). Importantly, NF1 associated tumors most frequently affect the optic nerve and chiasm (Packer et al., 1988; Listernick et al., 1997). The more common cerebellar PAs are on the other hand mostly sporadic, however, NF-association has been reported. PAs are seen in up to $15-20 \%$ of all patients with NF1 and typically manifest in early childhood.

The prognosis of patients with PA is in general excellent, with a 10-year survival rate of up to $94 \%$ (Koeller et al., 2004). Besides the intrinsic biological behavior, several other factors influence the prognosis of patients with low-grade gliomas, including tumor location, age at diagnosis, extent of resection, histological subtype, presence of diencephalic syndrome, cerebrospinal fluid (CSF) dissemination and association with NF1 (Mirow et al., 2014). Among PAs those arising in the visual pathway or hypothalamus have the least favorable outcome (Gajjar et al., 1997). Particularly very young children with visual pathway gliomas have a more aggressive clinical course. It has been shown that age $<6$ months at diagnosis, diencephalic syndrome and primary CSF dissemination constitute unfavorable risk factors for survival of LGG patients (Mirow et al., 2014). NF1-associated PAs tend to have a better prognosis than sporadic PAs (Rodriguez et al., 1990). Treatment strategies of LGGs highly depend on the tumor location. Surgical resection is considered the treatment of choice for most LGGs and is often curative (Gnekow et al., 2012). However, many tumors are not amenable to complete resection 
and warrant other or additional treatment options such as chemotherapy and/or radiotherapy. Hypothalamic/chiasmatic gliomas are rarely amenable to gross-total resection (GTR) and are associated with higher operative risk. To avoid the deleterious late effects of external beam radiotherapy on neurocognitive development and potential risks for endocrinopathy and secondary tumor induction, chemotherapy is preferred in children younger than 5 years of age and especially in infants (Merchant et al., 2009; Gnekow et al., 2012). Until now no single treatment strategy has been proven to be superior to others. Importantly, chemotherapy regimes successfully applied in older children, like the combination of vincristine and carboplatin, are unfortunately less effective in children $<1$ year of age (Gnekow et al., 2012). Thus, further improvement of therapeutical strategies is warranted in young children with visual pathway/hypothalamic LGGs.

CSF dissemination of LGGs is a strong predictive factor of progression and strongly influences the therapy regimen as well as the overall prognosis (Hukin et al., 2002; Bian et al., 2013). It has been documented that approximately 5\% of the LGGs are associated with CSF dissemination, with dissemination present at initial diagnosis in about 3\% (Mirow et al., 2014). As mentioned above, recent data indicate that CSF dissemination represents an unfavorable prognostic factor for progression of patients with LGG.

\subsection{Pilomyxoid astrocytoma}

Pilomyxoid astrocytoma (PMA) is a recently described rare low-grade tumor entity that shares several features with PAs. Nevertheless, PMAs have unique histopathological and clinical features that differ from those of PAs (Janisch et al., 1985; Tihan et al., 1998). The described subtle histologic characteristics include the presence of a markedly myxoid matrix, with small, compact monophasic-monomorphic piloid cells often arranged radially around vessels (angiocentric pattern) (Cottingham et al., 1996; Tihan et al., 1999). Furthermore, PMAs lack a biphasic pattern, protoplasmic cells, an oligodendroglioma-like pattern, Rosenthal fibers and eosinophil bodies that characterize PAs. As opposed to PA, PMA may occasionally show rare mitotic figures and tumor infiltration of the surrounding neuropil. Microcalcifications in PMA specimens are uncommon (Tihan et al., 1998; Tihan et al., 1999). PMAs are typically diagnosed 
at earlier ages than PAs (mean age at diagnosis: 18 months vs. 58 months) (Komotar et al., 2004a; Komotar et al., 2004b). Correspondingly, an increase in head size, split sutures and a bulging fontanelle may be the first symptoms. Similarly to PAs, initial symptoms depend on the site of the tumor. Although both tumors can occur anywhere along the neuraxis, the predilectional site of PMA, in contrast to PA, is the chiasmatic-hypothalamic region, rather than the infratentorial compartment (Komotar et al., 2004a). Initial studies described the more aggressive nature of PMAs with worse clinical outcome and higher recurrence rates. Thus, PMAs are designated grade II tumors in the latest WHO classification (Louis et al., 2007). Furthermore, earlier observations indicated a higher rate of CSF dissemination of PMAs compared to PAs, and also reported tumor recurrence in form of meningeal tumor spread (Komotar et al., 2004a). However, as primary dissemination of LGGs is generally more frequent in younger children (Gnekow et al., 2012), it remains to be elucidated whether PMAs more frequently disseminate via the CSF than PAs in the very young pediatric population. To date, no validated specific treatment protocol exists for PMA patients. There are only a few limited reports regarding the treatment strategies of PMA (Komotar et al., 2004b; Komotar et al., 2005b; Rumboldt et al., 2006; Ceppa et al., 2007; Tsugu et al., 2009). As for other LGGs, GTR should be aimed in these patients. However, the predilectional localization in the chiasmatichypothalamic region often does not permit total resection. In case of an irresectable tumor, subtotal resection and/or primary CSF dissemination additional treatment options like radiotherapy or chemotherapy may be applied. In a recent case series Tsugu et al. reported on the positive effects of cisplatin/carboplatin-based multiagent chemotherapy (Tsugu et al., 2009). Furthermore, experiences from earlier reports of successful management of disseminated, aggressive PAs may help the management of children with PMA (Mamelak et al., 1994; McCowage et al., 1996). The emerging understanding of the genetic and molecular background of tumorigenesis, such as the recently recognized importance of the MAPK pathways, may allow us to develop improved treatments for PA and PMA in the future (Aktas et al., 2014). 


\subsection{Computed tomography (CT) and magnetic resonance imaging (MRI)}

The first commercially applicable CT scanner was invented by Sir Godfrey Hounsfield in 1967 at the EMI Central Research Laboratories in Hayes, United Kingdom (Oransky, 2004; Beckmann, 2006). The first EMI-Scanner was installed in Atkinson Morley Hospital in Wimbledon, England, and the first patient brain-scan was done on October 1, 1971. CT is an imaging procedure that uses special x-ray equipment to create tomographic images of the examined body part (Kalender, 2000). CT produces a volume of data that can be manipulated in order to demonstrate various structures based on their ability to block the x-ray beam. Materials and tissues that have higher ability to absorb x-ray (e.g., calcium, iron) appear brighter (hyperdense), whereas those with less absorption (e.g., fat) appear darker (hypodense) on CT scans. Since its introduction in the 1970s, CT has become a crucial tool in medical imaging to supplement x-rays, ultrasonography and in some instances the MRI. CT scanning of the head is typically used to detect infarction, tumors, calcifications, hemorrhage and bone trauma (Igbaseimokumo, 2009). As cerebral gray matter contains more cell bodies, it shows a higher radiodensity on CT scans. Conversely, white matter consists of predominantly axons and surrounding glial elements, thus it appears hypodense in relation to cortex. Pathological hypodensity in the brain can indicate, among others, edema and infarction. Markedly hyperdense structures indicate calcification or hemorrhage. Brain tumors can show various density, depending on their cellularity; highly cellular tumors such as lymphomas may appear hyperdense, whereas low-grade brain tumors mostly show low density values.

MRI uses a powerful magnetic field (routinely at least 1 Tesla), radiofrequency pulses and a computer to produce detailed images of body organs (Westbrook, 2008). MRI is a noninvasive method that does not use ionizing radiation (x-ray). The MRI technique is based on proton imaging. Protons are positively charged particles in the nucleus of every atom. Since hydrogen nucleus $\left(\mathrm{H}^{+}\right)$is the most abundant nucleus in the human body, it gives the best signal, thus the amount of hydrogen highly determines the MRI signal. Protons have a continuous rotatory movement called spin that generates current. Every current induces a small surrounding magnetic field. Without any external influence the protons in the human body move randomly. However, when a high-field external magnetic field is applied (i.e., the patient is placed in the magnet), the protons start to align and spin parallel or anti-parallel to the magnetic field. 
Subsequently a radiofrequency (RF) pulse is sent and some protons go to a higher energy level causing the formation of the so-called transverse magnetization. Parallely, the so-called longitudinal magnetization is reduced. When the RF pulse is turned off, the longitudinal magnetization recovers with the time constant T1 (longitudinal relaxation) and the transverse magnetization gradually decreases with the time constant T2 (transverse relaxation). Both constants are tissue-dependent. The change in the transverse magnetization produces electric current which is received by the coils of the MRI machine as signal. Signal is transformed into an image by a complex mathematical process, called Fourier transformation. The weighting of the acquired image is determined by the applied TR (repetition time) and TE (echo time), which characterize the timing of the RF pulse and the reception of the signal. The three major weightings in MR imaging are the T1-weighted, the T2-weighted and the proton-weighted sequences that allow depicting different aspects of the tissues.

Diffusion weighted imaging (DWI) is an MRI technique in which dedicated phasedefocusing and refocusing gradients allow the evaluation of microscopic water diffusion within tissues. Diffusion sequences in present use are the so called echo planar imaging (EPI) ultrafast gradient echo sequences that allow the measurement of water diffusion within a short time (routinely $<1$ minute). The calculated apparent diffusion coefficient (ADC) maps represent an absolute measure of average diffusion for each voxel. Regions with reduced water diffusion appear dark on ADC maps and show high signal on DWI. DWI and ADC maps are useful in evaluation of brain infarcts and several other brain lesions. ADC values are reported to be proportional with cell density. Thus, certain brain tumors with markedly differing cellularity (e.g.: medulloblastoma vs. PA) may be more reliably differentiated based on ADC values (Rumboldt et al., 2006).

MRI contrast agents are chemical substances used to increase the differences between different tissues or between normal and abnormal tissue, by altering the relaxation times (Goodden et al., 2014). They have been shown to improve lesion identification and characterization. MRI contrast agents are classified according to the different changes in relaxation times after their injection. The most widely used substances are the gadolinium containing positive contrast agents. They cause a reduction in the T1 relaxation time (causing increased signal intensity on T1 weighted images). Gadolinium is a rare earth metal with an atomic number of 64; free gadolinium is highly toxic. To prevent toxicity gadolinium is used in 
different forms of chelate complexes (e.g., gadopentetate dimeglumine) that are totally and rapidly excreted renally. The mechanism of $\mathrm{MR}$ contrast enhancement in the brain is multifactorial and depends upon various factors like spin density, diffusion and perfusion of the contrast agent as well as the state of the blood-brain barrier.

\subsection{Imaging of PA and PMA}

Although some tumors show specific MRI features, a reliable prediction of tumor histology or grade by neuroimaging alone is often not possible. In some cases further information can be gained by an additional CT scan with respect to tumor calcification, hemorrhage or tumor cell density. Additionally, modern MRI techniques like DWI, diffusion tensor imaging (DTI) or MRspectroscopy (MRS) can be implemented in case of diagnostic uncertainty (Rumboldt et al., 2006; Wagnerova et al., 2012; Porto et al., 2013).

PAs appear typically well-demarcated on CT and MRI (Lee et al., 1989). On CT images cystic tumor portions appear hypodense and solid parts show iso- to hypoattenuation compared to cerebral cortex. PAs are isointense to hypointense relative to normal cortical brain parenchyma on T1-weighted MR images and usually show hyperintense signal on T2-weighted scans. Although PAs may show different morphological patterns partially depending on the site of the tumor, a cystlike mass with enhancing nodule represents the classical, most commonly encountered manifestation. Intratumoral hemorrhage is a rare phenomenon, however, hemorrhage may occasionally be the first sign of a PA that prompts the initial radiological diagnosis (Golash et al., 1998; Shibahara et al., 2009).

Although initial observations described the typical imaging appearance of PMAs, further comparative studies could not provide unequivocal radiological features that may differentiate PMAs from PAs. Some reports are even at odds with respect to signal behavior of PMAs, or in terms of tumor infiltration of the adjacent brain tissue (Arslanoglu et al., 2003; Komotar et al., 2008; Lee et al., 2011). 


\subsection{Aims of the study}

Due to the worse prognosis of PMAs it is beneficial to preoperatively differentiate these patients using imaging methods. This effort can help to predict the prognosis and may prompt more aggressive therapeutic approaches in the future; however, distinct PMA-specific treatment suggestions have not yet been set up.

The purpose of the present study was to search for imaging features that may reliably differentiate PMAs from PAs preoperatively. We analyzed semi-quantitatively MRI and CT characteristics of a relatively large series of pediatric patients collected from the German SIOP/HIT-LGG (SIOP: Société Internationale D`Óncologie Pédiatrique; HIT: Hirntumor) comprehensive multicenter prospective trials. Furthermore, to elucidate whether PMAs more frequently disseminate via the CSF than PAs in the very young pediatric population we compared the occurrence of imaging evidences of CSF tumor dissemination between age matched children with PMA and PA, respectively. 


\section{MATERIAL AND METHODS}

\subsection{Study population}

MRI studies were collected from the brain tumor database of the German Neuroradiological Reference Center for Pediatric Brain Tumors which is located in the Department of Neuroradiology of the "Universitätsklinikum Würzburg”. All children were involved in one of the past SIOP/HIT-LGG comprehensive multicenter trials (LGG 1996 and 2004). The whole database, including patients of these trials comprises to date of 2569 patients with various LGGs. Patients selected for the study were diagnosed with brain tumor between 2004 and 2013. MRI studies were performed in various radiological centers with MR scanners of different manufacturers at 1.0-3.0 Tesla field strength. From the technical point of view, a minimum of a non-contrast T2-weighted sequence as well as a contrast enhanced T1-weighted sequence in at least one plane and without severe motion artifacts were considered sufficient for inclusion in our study. A non-contrast T1-weighted sequence was also performed in all but one patient selected for the purpose of the present study. Several, but not all patients of the study population have also undergone spinal MRI scan(s) either at the time of the diagnosis or at follow-up. Only cases with centrally confirmed histopathological diagnosis [evaluated by Prof. Dr. Torsten Pietsch in the Brain Tumor Reference Center of the DGNN (Deutsche Gesellschaft für Neuropathologie und Neuroanatomie) located at the Institute of Neuropathology, University of Bonn Medical Center] of the different tumor entities were included in our study. Histological and immunohistochemical studies were performed with formalin-fixed, paraffin-embedded tissue. Furthermore, immunohistochemical staining for glial fibrillary acidic protein (GFAP) and Ki-67 was performed using the avidin-biotin-peroxidase method.

All available cases with the histopathological diagnosis of PMA that met the inclusion criteria were used for our study purpose, regardless of age or tumor location. Thus, the study group of PMAs included 13 children with chiasmatic-hypothalamic PMAs and 2 children with brainstem PMAs (age range: 4 months-7 years; median: 1.9 years). In addition, the reference histopathological evaluation encountered a few cases of PAs with focal pilomyxoid features. These tumors were considered as a separate group in our analysis $(n=8$, age range: 6 months-10.8 
years; median: 6.7 years). The comparison group consisted of 32 children with PA (age range: 4 months-10 years; median: 4.3 years). We included all PA cases that met the following inclusion criteria: age less than 11 years at tumor diagnosis, histopathological diagnosis of PA WHO Grade I confirmed by evaluation of the tumor specimen by the Brain Tumor Reference Center of the DGNN, and chiasmatic-hypothalamic tumor localization. The upper age limit for PA patients was defined according to the age of the oldest child with the histopathological diagnosis of PA with pilomyxoid features. Since the vast majority of PMAs occurred in the chiasmatichypothalamic localization, only PAs in the same localization (tumors confined to this region without extension to the optic nerves or beyond the optic tracts) were included in the comparison group. NF1 was considered as exclusion criterion (Table 1).

\subsection{Image analysis}

The retrospective review of MRI scans was performed by the author of the present dissertation in consensus with a more experienced neuroradiologist (M.W.-M.). MRI and CT scans were analyzed according to standardized criteria adapted from the routine image evaluation of our Neuroradiological Reference Center. The tumor diameters were measured in three orthogonal dimensions (along the axial, coronal and sagittal axes). Tumor volume was calculated according to a common approximation formula (a x b x c x 0.5; in $\mathrm{cm}^{3}$ ) (Table 1a). Another analyzed feature was the presence of cysts within the tumor, and their size (small/large, with a diameter $>1 \mathrm{~cm}$ being considered as large). T1- and T2- signal intensity of the tumor was defined in relation to that of the cortex (Table 2a). Since many tumors showed portions with different signal intensity, the following categories were introduced for tumor signal characteristics on T1weighted scans: hypointense, hypointense/isointense and isointense. Similarly, tumors were categorized in the following groups with respect to T2 signal intensity: hyperintense, hyperintense/hypointense. We registered the signal homogeneity of the solid tumor mass on T2weighted sequences (inhomogeneous, predominantly inhomogeneous, predominantly homogeneous, homogeneous) and the demarcation of the tumor from the adjacent brain tissue (well-defined, predominantly well-defined or ill-defined borders). We also searched for possible peritumoral edema and hydrocephalus (Table 1b). Mild hydrocephalus was defined as slight 
enlargement of the ventricles, moderate hydrocephalus was defined as enlargement of the ventricles with signs of CSF diapedesis around the ventricular margins, whereas severe hydrocephalus was defined as profound enlargement of the ventricles accompanied by narrowing of the external CSF space. An additional evaluated parameter was the pattern of gadolinium enhancement within the solid tumor volume (Table 2b). The intensity and homogeneity of the enhancement, as well as the percentage of enhancing solid tumor volume were estimated semiquantitatively as follows. We applied the categories no contrast enhancement, slight contrast enhancement, moderate contrast enhancement and intense contrast enhancement; in addition contrast enhancement was either heterogeneous or predominantly homogeneous. As none of the tumors showed completely homogeneous enhancement, this category was not applied. The percentage of enhancing solid tumor volume was estimated and the following categories were implemented: $0 \%, 1-25 \%, 26-50 \%, 51-75 \%, 76-100 \%$. We also searched for the presence of diffusion restriction within the tumors, if DWI sequences were available. We finally recorded the status of macroscopic meningeal dissemination [either M2 or/and M3, according to the Chang classification adopted from medulloblastoma staging; (Chang et al., 1969; Phi et al., 2011)] at the time of diagnosis, and in available follow-up scans (Table 3). The median "imaging" follow up for PMA was 1.1 years (min.: no follow-up, max.: 7.2 years) and that for PA was 3.2 years (min.: 0.2 years; max.: 8.3 years). When provided by the external referring centers, CT scans were analyzed with a focus on the density of the solid tumor volume. Similar to the evaluation of MRI signal intensity, the tumor density was defined in relation to that of the cortex. We applied the categories hypodense, hypodense/isodense, hypodense/hyperdense. Additionally, we searched for the presence of tumor calcifications and intratumoral hemorrhage.

\subsection{Statistical analysis}

After evaluation of the scans according to these imaging parameters, comparisons were performed in order to test for differences of MRI and CT characteristics between the groups of PMAs and PAs. The selection of the appropriate statistical method was based on the general guidelines provided by the Institiute of Digital Research and Education, UCLA (http://www.ats.ucla.edu/stat/mult_pkg/whatstat/). In case of continuous variables (age and tumor 
volume), the Shapiro-Wilk test was performed to test for normal distribution. Since neither age nor tumor size showed normal distribution the Mann Whitney $U$ test was carried out for intergroup comparisons. For categorical variables with $\geq 2$ categories the Chi-squared test was performed; in case of 2 categories and if at least one cell of the contingency table had an expected frequency of five or less, the Fisher's exact test was performed. The occurrence of CSF dissemination on MRI scans was also compared using the Chi-squared test; in addition, a binary logistic regression analysis was applied to evaluate the effect of age at diagnosis and histological diagnosis (PMA vs. PA) on the occurrence of CSF dissemination (http://core.ecu.edu/psyc/wuenschk/MV/Multreg/Logistic-SPSS.PDF). P-values $<0.05$ were considered as statistically significant and due to the limited number of subjects no corrections for multiple comparison were applied. The software PASW Statistics for Windows Version 18.0 (SPSS Inc., 2009, Chicago, IL, USA) was used for all statistical analyses in our study.

\subsection{Study design}

As demonstrated in Table 1 (comparison I. vs. II.), the first comparison was carried out between the whole group of children with PMA $(n=15)$ and the whole group of children with PA $(n=32)$. Since the PMA group was somewhat heterogeneous with respect to tumor location, and the median age of the two groups was slightly different (patients with PMA were generally younger than those with PA), a further comparison was carried out between children with chiasmatic-hypothalamic PMAs (all younger than 6 years) and children with PAs of the same location and corresponding age (i.e., all younger than 6 years). Patients with PAs with pilomyxoid features had a wide age range and this group consisted of tumors of various locations (column V. in Table 1). Thus, we present imaging features of these tumors descriptively, without statistical comparison to the other two groups. 


\section{RESULTS}

Comparison between children with PMA and children with PA (see comparison I. vs. II. in Tables 1, 2 and 3)

Children with PMA were generally younger at tumor diagnosis than those with PA (median age: 1.9 vs. 4.3 years, respectively; $\mathrm{p}=0.05$ ). There was no significant difference between the two groups with respect to gender distribution. The tumor size correlated with the age at diagnosis in neither of the groups. Tumor volume and tumor margin characteristics were also similar in the two groups; the tumor border of most PMAs and PAs were well-defined or predominantly welldefined. Cystic tumor portions were present in the majority of PAs (17 of 32) but only in the minority of PMAs (3 of 15; $\mathrm{p}=0.03$ ) (Figure 1). Furthermore, in a few PAs cystic tumor components were dominant, whereas this did not apply to any PMAs. We did not find differences in signal characteristics on non-contrast T1- and T2-weighted scans. The texture of solid tumor was most often inhomogeneous on T2-weighted scans in both PMAs and PAs. Homogeneity of contrast enhancement was, however, significantly more often predominantly homogeneous in PMAs ( $\mathrm{p}=0.006$ ) (Figure 1). There was no difference regarding the intensity of contrast enhancement or the percentage of enhancing tumor portion; the vast majority of tumors in both groups enhanced intensely and at least $50 \%$ of the solid tumor mass showed contrast enhancement. Approximately half of the children (in both groups) had mild to severe hydrocephalus at the time of the first MRI scan. Peritumoral edema was seen only in few cases. Interestingly, one of the PAs showed a tumor portion with restricted diffusion and correspondingly low T2 signal as a sign of focal high cellularity (Appendix Figure I.). None of the other PMAs and PAs demonstrated restricted diffusion. Intratumoral hemorrhage was more often seen in PMAs in comparison to PAs $(\mathrm{p}=0.047)$ (Figure 1). Tumor calcification was observed altogether in 2 PAs and in none of the PMAs.

Although CSF dissemination was more frequent in cases with PMA ( $\mathrm{p}=0.034)$, when applying the logistic regression model with age and tumor types as predictors, none of them appeared to be a significant predictor of meningeal tumor spread. 
Comparison between children with chiasmatic-hypothalamic PMA (age $<6$ years) and children with PA with age at diagnosis less than 6 years (see comparison III. vs. IV. in Tables 1, 2 and 3)

Neither age at tumor diagnosis (median age for PMA: 1 year, median age for PA: 2.5 years; n.s.) nor gender distribution differed between the two groups. There was no difference with respect to the volume of solid tumor mass. Cystic tumor components were present in 12 of the 22 PAs and in 3 of the 13 PMAs ( $\mathrm{p}=0.069$ ) (Figure 2). The solid tumor mass was, however, dominant in most tumors (in all PMAs and in 18 PAs). We did not find apparent differences in the sharpness of tumor margins or in signal characteristics on T1- and T2-weighted scans. T2 signal homogeneity appeared to be different with more PMAs showing predominantly homogeneous or homogeneous signal ( $\mathrm{p}=0.026$ ) (Figure 2). Contrast enhancement was intense in the majority of both tumor types. The homogeneity of contrast enhancement differed significantly between the two groups as predominantly homogeneous enhancement was more often seen in PMAs than in PAs ( $\mathrm{p}=0.05$ ) (Figure 2). The vast majority of both tumors showed enhancement of at least $50 \%$ of the solid tumor mass. We did not find differences when comparing the presence of peritumoral edema (most tumors were not surrounded by edema) or hydrocephalus. There was a trend for more frequent intratumoral hemorrhage in PMAs (4 of the 8 PMAs vs. 1 of the 11 PAs; $\mathrm{p}=0.1$ ). None of the PMAs showed restricted diffusion.

MRI evidence of CSF dissemination at the time of tumor diagnosis and in the available follow-up period could be significantly more often observed in PMAs than in PAs ( $\mathrm{p}=0.02$ and $\mathrm{p}=0.05$, respectively). In addition, the logistic regression analysis revealed a stronger effect of tumor type on the occurrence of CSF dissemination than of age ( $\mathrm{p}=0.05$ vs. $\mathrm{p}=0.12$ ).

Representative images of two children with PMA and a child with PA, respectively, are illustrated in Appendix Figures II-IV.

Imaging characteristics of PAs with pilomyxoid features (see column $\boldsymbol{V}$. in Tables 1, 2 and 3)

This group consisted of children of various age (6 months to 10.8 years). Furthermore, the tumors were heterogeneous with respect to their localization (3 in the chiasmatic-hypothalamic region, 1 in the cerebellum, 1 involving the mesencephalon, 1 located adjacent to the lateral 
ventricle and 2 involving the thalamus) and imaging appearance. Tumor cysts were seen in three of the eight tumors, with one case where the cystic component predominated the tumor. Sharpness of the tumor margins was of heterogenous nature, and peritumoral edema was present in one case. Mild to severe hydrocephalus was seen in the majority of the children. All tumors were hypointense on T1- and hyperintense on T2-weighted images and most of them showed an inhomogeneous texture. Interestingly, one of the tumors did not enhance gadolinium, whereas most of them enhanced profoundly. Contrast enhancement was inhomogeneous in four, and predominantly homogeneous in three cases. No tumors showed areas with diffusion restriction or calcifications. Intratumoral hemorrhage was observed in one case. MRI signs of meningeal tumor spread were evident in only one case. An example of this tumor group is presented in

\section{Appendix Figure V.}

An example for the typical histopathological appearance of a PMA is demonstrated in Appendix Figure VI. 
Table 1a: Patient demographic data and tumor features

\begin{tabular}{|c|c|c|c|c|c|c|c|}
\hline & $\begin{array}{c}\text { I. } \\
\text { PMA }\end{array}$ & $\begin{array}{l}\text { II. } \\
\text { PA }\end{array}$ & 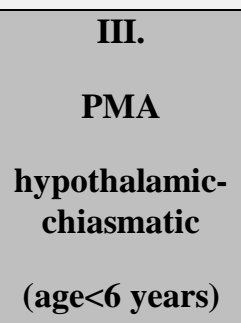 & $\begin{array}{c}\text { IV. } \\
\text { PA } \\
\begin{array}{c}\text { hypothalamic- } \\
\text { chiasmatic } \\
\text { (age<6 years) }\end{array}\end{array}$ & $\begin{array}{c}\text { V. } \\
\text { PA with pilomyxoid } \\
\text { features }\end{array}$ & $\begin{array}{l}\text { I. vs. } \\
\text { II. }\end{array}$ & $\begin{array}{l}\text { III. vS. } \\
\text { IV. }\end{array}$ \\
\hline $\mathbf{N}$ & 15 & 32 & 13 & 22 & 8 & n.a. & n.a. \\
\hline $\begin{array}{c}\text { Age (y) } \\
\text { median/min/max }\end{array}$ & $1.9 / 0.3 / 7.0$ & 4.3/0.3/10 & $1.0 / 0.3 / 6.0$ & $2.5 / 0.3 / 5.9$ & $6.7 / 0.5 / 10.8$ & $p=0.05$ & n.s. \\
\hline $\begin{array}{c}\text { Gender } \\
\mathrm{M} / \mathrm{F}\end{array}$ & $10 / 5$ & $20 / 12$ & $8 / 5$ & $15 / 7$ & $8 / 0$ & n.s. & n.s. \\
\hline $\begin{array}{c}\text { Location } \\
\text { hypothalamic- } \\
\text { chiasmatic/other }\end{array}$ & $13 / 2$ & $32 / 0$ & $13 / 0$ & $22 / 0$ & $3 / 5$ & n.a. & n.a. \\
\hline $\begin{array}{c}\text { Tumor volume }\left(\mathrm{cm}^{3}\right) \\
\text { median/min/max }\end{array}$ & 19.0/4.7/70.4 & 21.4/2.9/214.9 & $24.6 / 8.4 / 70.4$ & 26.8/2.9/214.9 & 46.3/3.8/112.4 & n.s. & n.s. \\
\hline $\begin{array}{c}\text { Cyst(s) present } \\
\text { yes/no }\end{array}$ & $3 / 12$ & $17 / 15$ & $3 / 10$ & $12 / 10$ & $3 / 5$ & $p=0.03$ & $\mathrm{p}=0.069$ \\
\hline $\begin{array}{c}\text { Cyst size } \\
<1 \mathrm{~cm} />1 \mathrm{~cm}\end{array}$ & $3 / 0$ & $10 / 7$ & $3 / 0$ & $5 / 6$ & $2 / 1$ & n.s. & n.s. \\
\hline
\end{tabular}

Abbreviations: PMA: pilomyxoid astrocytoma; PA: pilocytic astrocytoma; M: male; F: female; min: minimum; max: maximum; n.s.: not significant; n.a.: not applicable 
Table 1b: Tumor features and secondary phenomena

\begin{tabular}{|c|c|c|c|c|c|c|c|}
\hline & $\begin{array}{c}\text { I. } \\
\text { PMA }\end{array}$ & $\begin{array}{l}\text { II. } \\
\text { PA }\end{array}$ & $\begin{array}{c}\text { III. } \\
\text { PMA } \\
\text { hypothalamic- } \\
\text { chiasmatic } \\
\text { (age<6 years) }\end{array}$ & $\begin{array}{c}\text { IV. } \\
\text { PA } \\
\text { hypothalamic- } \\
\text { chiasmatic } \\
\text { (age<6 years) }\end{array}$ & $\begin{array}{c}\text { V. } \\
\begin{array}{c}\text { PA with pilomyxoid } \\
\text { features }\end{array}\end{array}$ & I. vs. II. & $\begin{array}{c}\text { III. vS. } \\
\text { IV. }\end{array}$ \\
\hline $\begin{array}{c}\text { Solid tumor } \\
\text { dominant } \\
\text { yes/no }\end{array}$ & $15 / 0$ & $28 / 4$ & $13 / 0$ & $18 / 4$ & $7 / 1$ & n.s. & n.s. \\
\hline Margin & $\begin{array}{c}\text { well defined: } 10 \\
\text { predominantly well } \\
\text { defined: } 4 \\
\text { ill defined: } 1\end{array}$ & $\begin{array}{l}\text { well defined: } 17 \\
\text { predominantly well } \\
\text { defined: } 15 \\
\text { ill defined: } 0\end{array}$ & $\begin{array}{c}\text { well defined: } 9 \\
\text { predominantly well } \\
\text { defined: } 3 \\
\text { ill defined: } 1\end{array}$ & $\begin{array}{c}\text { well defined: } 11 \\
\text { predominantly well } \\
\text { defined: } 11 \\
\text { ill defined: } 0\end{array}$ & $\begin{array}{c}\text { well defined: } 3 \\
\text { predominantly well } \\
\text { defined: } 3 \\
\text { ill defined: } 2\end{array}$ & n.s. & n.s. \\
\hline $\begin{array}{c}\text { Peritumoral edema } \\
\text { yes/no }\end{array}$ & $3 / 12$ & $4 / 28$ & $3 / 10$ & $4 / 18$ & $1 / 7$ & n.s. & n.s. \\
\hline Hydrocephalus & $\begin{array}{c}\text { no: } 7 \\
\text { mild: } 3 \\
\text { moderate: } 3 \\
\text { severe: } 2\end{array}$ & $\begin{array}{c}\text { no: } 17 \\
\text { mild: } 4 \\
\text { moderate: } 4 \\
\text { severe: } 7\end{array}$ & $\begin{array}{c}\text { no: } 5 \\
\text { mild: } 3 \\
\text { moderate: } 3 \\
\text { severe: } 2\end{array}$ & $\begin{array}{c}\text { no: } 14 \\
\text { mild: } 3 \\
\text { moderate: } 1 \\
\text { severe: } 4\end{array}$ & $\begin{array}{c}\text { no: } 1 \\
\text { mild: } 3 \\
\text { moderate: } 2 \\
\text { severe: } 2\end{array}$ & n.s. & n.s. \\
\hline
\end{tabular}

Abbreviations: PMA: pilomyxoid astrocytoma; PA: pilocytic astrocytoma; n.s.: not significant 
Table 2a: Signal characteristics on T1- T2- and diffusion-weighted MR images

\begin{tabular}{|c|c|c|c|c|c|c|c|}
\hline & $\begin{array}{c}\text { I. } \\
\text { PMA }\end{array}$ & $\begin{array}{l}\text { II. } \\
\text { PA }\end{array}$ & $\begin{array}{c}\text { III. } \\
\text { PMA } \\
\text { hypothalamic- } \\
\text { chiasmatic } \\
\text { (age<6 years) }\end{array}$ & $\begin{array}{c}\text { IV. } \\
\text { PA } \\
\begin{array}{c}\text { hypothalamic- } \\
\text { chiasmatic }\end{array} \\
\text { (age<6 years) }\end{array}$ & $\begin{array}{c}\text { V. } \\
\text { PA with pilomyxoid } \\
\text { features }\end{array}$ & I. VS. II. & $\begin{array}{l}\text { III. vS. } \\
\text { IV. }\end{array}$ \\
\hline T1 signal & $\begin{array}{c}\text { hypointense: } 14 \\
\text { hypointense/isointens: } 1 \\
\text { isointense: } 0\end{array}$ & $\begin{array}{c}\text { hypointense: } 20 \\
\text { hypointense/isointens: } 10 \\
\text { isointense: } 2\end{array}$ & $\begin{array}{c}\text { hypointense: } 12 \\
\text { hypointense/isointens: } 1 \\
\text { isointense: } 0\end{array}$ & $\begin{array}{c}\text { hypointense: } 13 \\
\text { hypointense/isointens: } 8 \\
\text { isointense: } 1\end{array}$ & $\begin{array}{c}\text { hypointense: } 7^{*} \\
\text { hypointense/isointens: } 0 \\
\text { isointense: } 0\end{array}$ & n.s. & n.s. \\
\hline T2 signal & $\begin{array}{c}\text { hyperintense: } 15 \\
\text { hyperintense/hypointense: } 0\end{array}$ & $\begin{array}{c}\text { hyperintense: } 26 \\
\text { hyperintense/hypointense: } \\
6\end{array}$ & $\begin{array}{c}\text { hyperintense: } 13 \\
\text { hyperintense/hypointense: } \\
0\end{array}$ & $\begin{array}{c}\text { hyperintense: } 18 \\
\text { hyperintense/hypointense: } \\
4\end{array}$ & $\begin{array}{c}\text { hyperintense: } 8 \\
\text { hyperintense/hypointense: } \\
0\end{array}$ & n.s. & n.s. \\
\hline $\begin{array}{c}\text { T2 signal } \\
\text { homogeneity }\end{array}$ & $\begin{array}{c}\text { inhomogeneous: } 9 \\
\text { predominantly } \\
\text { inhomogeneous: } 0 \\
\text { predominantly } \\
\text { homogeneous: } 5 \\
\text { homogeneous: } 1\end{array}$ & $\begin{array}{c}\text { inhomogeneous: } 25 \\
\text { predominantly } \\
\text { inhomogeneous: } 2 \\
\text { predominantly } \\
\text { homogeneous: } 4 \\
\text { homogeneous: } 1\end{array}$ & $\begin{array}{c}\text { inhomogeneous: } 7 \\
\text { predominantly } \\
\text { inhomogeneous: } 0 \\
\text { predominantly } \\
\text { homogeneous: } 5 \\
\text { homogeneous: } 1\end{array}$ & $\begin{array}{c}\text { inhomogeneous: } 20 \\
\text { predominantly } \\
\text { inhomogeneous: } 1 \\
\text { predominantly } \\
\text { homogeneous: } 1 \\
\text { homogeneous: } 0\end{array}$ & $\begin{array}{c}\text { inhomogeneous: } 6 \\
\text { predominantly } \\
\text { inhomogeneous: } 0 \\
\text { predominantly } \\
\text { homogeneous: } 2 \\
\text { homogeneous: } 0\end{array}$ & n.s. & $p=0.026$ \\
\hline $\begin{array}{l}\text { Diffusion } \\
\text { restriction } \\
\text { yes/no }\end{array}$ & $0 / 11$ & $1 / 23$ & $0 / 9$ & $1 / 15$ & $0 / 6$ & n.s. & n.s. \\
\hline
\end{tabular}

Note and abbreviations: PMA: pilomyxoid astrocytoma; PA: pilocytic astrocytoma; n.s.: not significant; *: no available non-contrast T1-weighted scan in one case. 
Table 2b: MRI contrast enhancing features

\begin{tabular}{|c|c|c|c|c|c|c|c|}
\hline & $\begin{array}{c}\text { I. } \\
\text { PMA }\end{array}$ & $\begin{array}{l}\text { II. } \\
\text { PA }\end{array}$ & 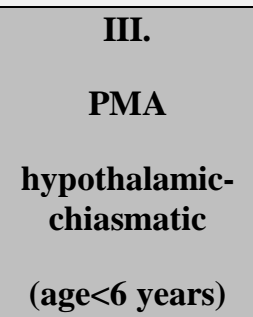 & $\begin{array}{c}\text { IV. } \\
\text { PA } \\
\begin{array}{c}\text { hypothalamic- } \\
\text { chiasmatic }\end{array} \\
\text { (age<6 years) }\end{array}$ & $\begin{array}{c}\text { V. } \\
\text { PA with pilomyxoid } \\
\text { features }\end{array}$ & I. vs. II. & $\begin{array}{l}\text { III. vs. } \\
\text { IV. }\end{array}$ \\
\hline $\mathrm{CE}$ intensity & $\begin{array}{c}\text { no CE: } 1 \\
\text { slight: } 0 \\
\text { moderate: } 1 \\
\text { intense: } 13\end{array}$ & $\begin{array}{c}\text { no CE: } 0 \\
\text { slight: } 1 \\
\text { moderate: } 5 \\
\text { intense: } 26\end{array}$ & $\begin{array}{c}\text { no CE: } 0 \\
\text { slight: } 0 \\
\text { moderate: } 1 \\
\text { intense: } 12\end{array}$ & $\begin{array}{c}\text { no CE: } 0 \\
\text { slight: } 0 \\
\text { moderate: } 3 \\
\text { intense: } 19\end{array}$ & $\begin{array}{c}\text { no CE: } 1 \\
\text { slight: } 1 \\
\text { moderate: } 0 \\
\text { intense: } 6\end{array}$ & n.s. & n.s. \\
\hline $\begin{array}{c}\text { CE } \\
\text { homogeneity }\end{array}$ & $\begin{array}{c}\text { inhomogeneous: } 7 \\
\text { predominantly } \\
\text { homogeneous: } 7\end{array}$ & $\begin{array}{c}\text { inhomogeneous: } 28 \\
\text { predominantly } \\
\text { homogeneous: } 4\end{array}$ & $\begin{array}{c}\text { inhomogeneous: } 6 \\
\text { predominantly } \\
\text { homogeneous: } 7\end{array}$ & $\begin{array}{c}\text { inhomogeneous: } 18 \\
\text { predominantly } \\
\text { homogeneous: } 4\end{array}$ & $\begin{array}{c}\text { inhomogeneous: } 4 \\
\text { predominantly } \\
\text { homogeneous: } 3\end{array}$ & $p=0.006$ & $p=0.05$ \\
\hline $\begin{array}{l}\text { Contrast } \\
\text { enhancing } \\
\text { portion of } \\
\text { solid tumor }\end{array}$ & $\begin{array}{c}\text { 0\%: } 1 \\
\text { 1-25\%: } 2 \\
\text { 26-50\%: } 1 \\
\text { 51-75\%: } 3 \\
\text { 76-100\%: } 8\end{array}$ & $\begin{array}{c}\text { 0\%: } 0 \\
\text { 1-25\%: } 1 \\
\text { 26-50\%: } 3 \\
\text { 51-75\%: } 4 \\
\text { 76-100\%: } 24\end{array}$ & $\begin{array}{c}\text { 0\%: } 0 \\
\text { 1-25\%: } 1 \\
\text { 26-50\%: } 1 \\
\text { 51-75\%: } 3 \\
\text { 76-100\%: } 8\end{array}$ & $\begin{array}{c}\text { 0\%: } 0 \\
\text { 1-25\%: } 1 \\
\text { 26-50\%: } 1 \\
\text { 51-75\%: } 4 \\
\text { 76-100\%: } 16\end{array}$ & $\begin{array}{c}\text { 0\%: } 1 \\
\text { 1-25\%: } 1 \\
\text { 26-50\%: } 1 \\
\text { 51-75\%:1 } \\
\text { 76-100\%: } 4\end{array}$ & n.s. & n.s. \\
\hline
\end{tabular}

Abbreviations: PMA: pilomyxoid astrocytoma; PA: pilocytic astrocytoma; CE: contrast enhancement; n.s.: not significant 
Table 3: Tumor characteristics on CT scan and CSF dissemination frequency

\begin{tabular}{|c|c|c|c|c|c|c|c|}
\hline & $\begin{array}{c}\text { I. } \\
\text { PMA }\end{array}$ & $\begin{array}{l}\text { II. } \\
\text { PA }\end{array}$ & $\begin{array}{c}\text { III. } \\
\text { PMA } \\
\text { hypothalamic- } \\
\text { chiasmatic } \\
\text { (age<6 years) }\end{array}$ & $\begin{array}{c}\text { IV. } \\
\text { PA } \\
\begin{array}{c}\text { hypothalamic- } \\
\text { chiasmatic }\end{array} \\
\text { (age<6 years) }\end{array}$ & $\begin{array}{c}\text { V. } \\
\text { PA with pilomyxoid } \\
\text { features }\end{array}$ & I. vs. II. & $\begin{array}{c}\text { III. vs. } \\
\text { IV. }\end{array}$ \\
\hline $\begin{array}{c}\text { Tumor } \\
\text { density on } \\
\text { CT scan }\end{array}$ & $\begin{array}{c}\text { hypodense: } 9 \\
\text { hypodense/isodense: } 0 \\
\text { hypodense/hyperdense: } 0\end{array}$ & $\begin{array}{c}\text { hypodense: } 8 \\
\text { hypodense/isodense: } 4 \\
\text { hypodense/hyperdense: } 3\end{array}$ & $\begin{array}{c}\text { hypodense: } 8 \\
\text { hypodense/isodense: } 0 \\
\text { hypodense/hyperdense: } 0\end{array}$ & $\begin{array}{c}\text { hypodense: } 6 \\
\text { hypodense/isodense: } 3 \\
\text { hypodense/hyperdense: } 2\end{array}$ & $\begin{array}{c}\text { hypodense: } 4 \\
\text { hypodense/isodense: } 0 \\
\text { hypodense/hyperdense: } 0\end{array}$ & $\mathrm{p}=0.07$ & n.s. \\
\hline $\begin{array}{c}\text { Intratumoral } \\
\text { hemorrhage } \\
\text { on CT scan } \\
\text { yes/no }\end{array}$ & $4 / 5$ & $1 / 14$ & $4 / 4$ & $1 / 10$ & $1 / 3$ & $p=0.047$ & $\mathrm{p}=0.10$ \\
\hline $\begin{array}{c}\text { Calcification } \\
\text { on CT scan } \\
\text { yes/no }\end{array}$ & $0 / 9$ & $2 / 13$ & $0 / 8$ & $2 / 9$ & $0 / 4$ & n.s. & n.s. \\
\hline $\begin{array}{c}\text { CSF } \\
\text { dissemination } \\
\text { yes/no }\end{array}$ & $7 / 8$ & $5 / 27$ & $7 / 5$ & $4 / 18$ & $1 / 7$ & $p=0.034$ & $p=0.05$ \\
\hline
\end{tabular}

Abbreviations: PMA: pilomyxoid astrocytoma; PA: pilocytic astrocytoma; n.s.: not significant 
Figure 1
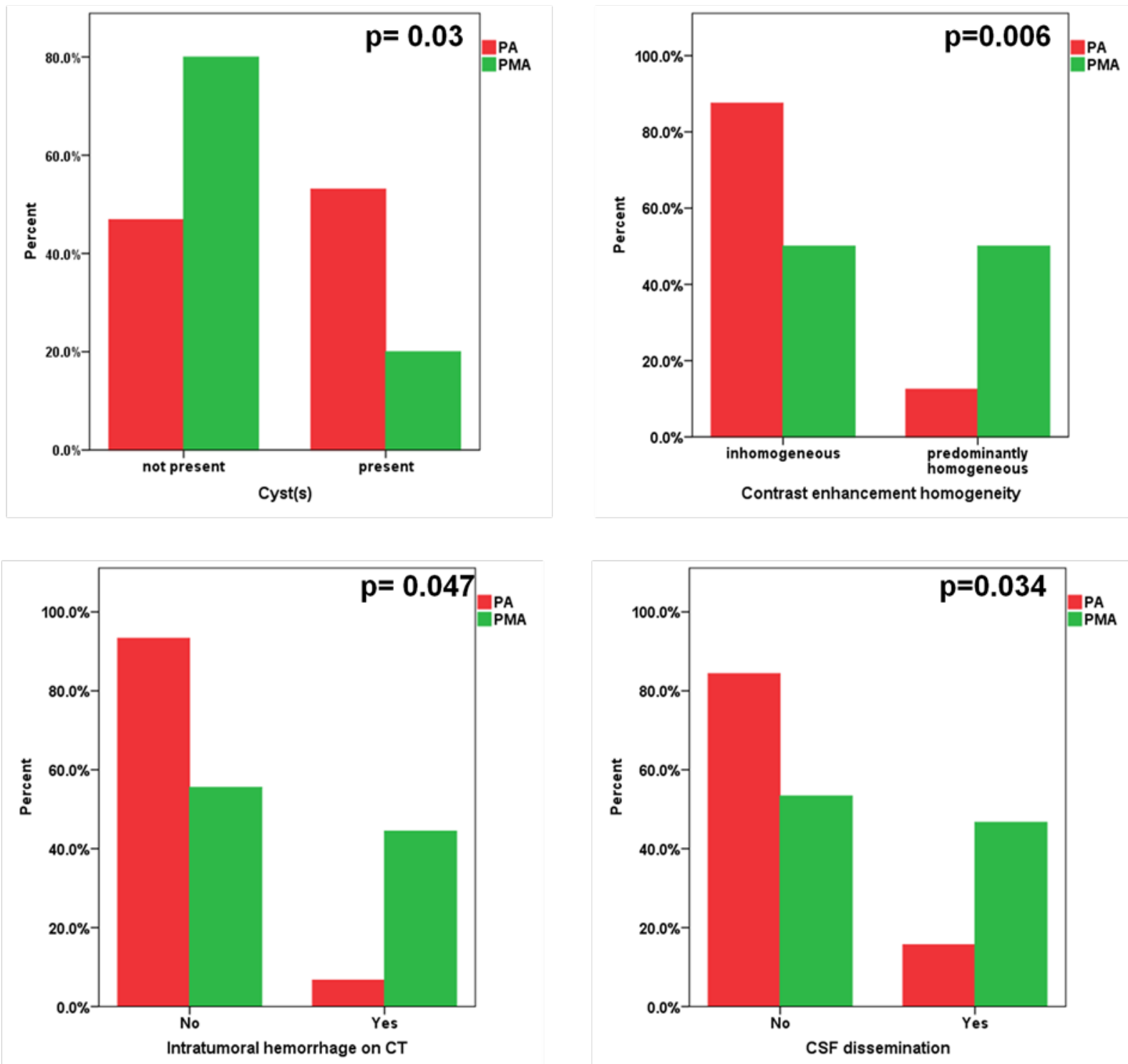

Bar graphs demonstrating the frequency of tumor cysts, contrast enhancement homogeneity of solid tumor portions, the occurrence of intratumoral hemorrhage and CSF dissemination potential, respectively, of PMAs vs. PAs (see comparison I. vs. II. in the Tables). 
Figure 2
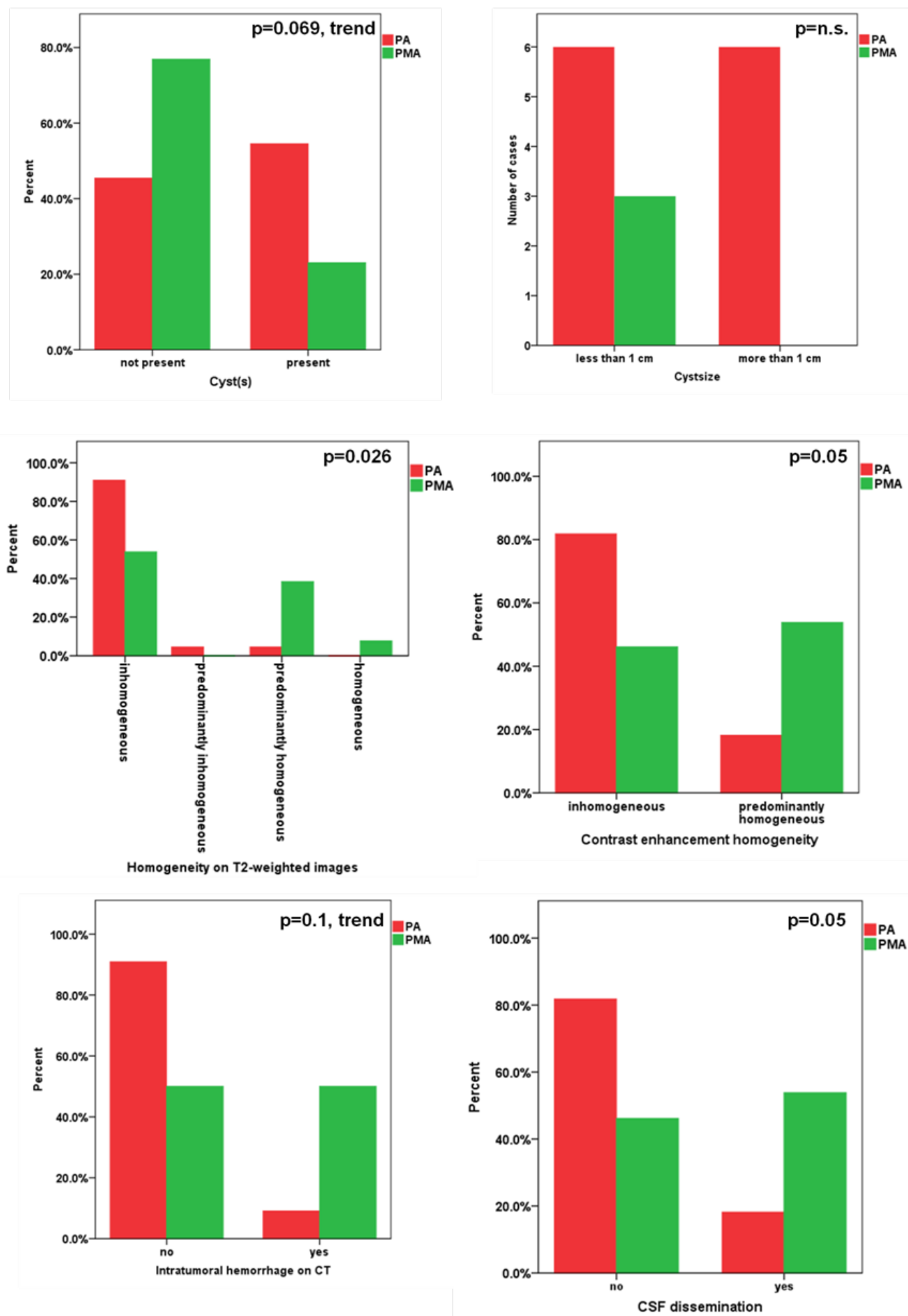

Bar graphs showing the comparison of different imaging features as well as CSF dissemination frequency of chiasmatic-hypothalamic PMAs vs. PAs (see comparison III. vs. IV. in the Tables). 


\section{DISCUSSION}

PMA is a recently described low-grade tumor of the central nervous system (CNS) that was earlier included in the group of PA, the most common histological group in pediatric LGGs. According to recent estimations PMAs constitute about $10 \%$ of all tumors previously diagnosed as PA (Bhargava et al., 2013). Initial studies documented the subtle but key histological differences between the two tumor entities (Janisch et al., 1985; Cottingham et al., 1996; Tihan et al., 1998; Tihan et al., 1999). The mean age at tumor diagnosis was initially documented to be much less for PMA patients than that for PA patients (18 months vs. 58 months); thus PMA was considered to be an immature variant of PA (Komotar et al., 2004a). Nevertheless, later studies reported adult PMA cases implicating that it is not strictly a pediatric tumor (Linscott et al., 2008; Bhargava et al., 2013). As being the German Neuroradiological Reference Center for Pediatric Brain Tumors, we have not encountered adult PMA cases. The presented data also confirm that age of PMA patients is below those of PA patients.

PMAs do not only histologically differ from PAs but also exhibit a different regional predilection. Although PMA may occur anywhere along the neuraxis, including the spinal cord (Komotar et al., 2005a), it is most often seen in the hypothalamic region (>75\%) (Tihan et al., 1999; Fernandez et al., 2003). Interestingly, several lines of evidence suggest that atypical locations of PMA are more common in older patients (Gottfried et al., 2003; Komotar et al., 2006; Mendiratta-Lala et al., 2007; Linscott et al., 2008). Correspondingly, 13 of the 15 children in our series had their PMA in the chiasma-hypothalamus region. One of our PMA patients with tumor location in the brainstem was the oldest in this histology group; the other child was 2.5 years old. In contrast, PA more often arises within the cerebellum and represents the most frequent posterior fossa tumor (Poretti et al., 2012).

Most CNS tumors associated with NF1 are PAs. Nevertheless, recent reports of PMAs associated with NF1 suggest that PMA may be another tumor entity that can occasionally occur in the context of this phakomatosis (Khanani et al., 2006; Rodriguez et al., 2008). Whether NF1linked PMAs show different radiological features or clinical aspects compared to their sporadic counterparts remains unclear. In our series of PMAs there was no proven case with NF1. To rule out the potential confounding effect of NF1-association we did not include children with NF1linked PAs in the comparison group. 
Komotar et al. initially described PMA as a well-circumscribed tumor without signs of peritumoral edema or parenchymal tumor invasion (Komotar et al., 2004b). In their series most tumors were solid and only the minority showed some cystic components. Signs of obstructive hydrocephalus were seen in more than $1 / 3$ of the cases. On T1-weighted images almost all tumors were isointense and contrast enhancement was typically homogeneous. The predominantly solid nature of PMA was confirmed by other investigators, who also emphasized the extension of the T2 signal abnormality into the adjacent deep white and gray matter as a distinguishing radiological feature of PMA (Arslanoglu et al., 2003; Komakula et al., 2007). Correspondingly, pathological metabolic alterations demonstrated by MR-spectroscopy may be seen outside their enhancing margin likely indicating their more aggressive nature (Morales et al., 2007). As MR-spectroscopic data are to date limited, it remains to be elucidated whether this method could be useful in the differentiation of PMAs from PAs (Cirak et al., 2005; Morales et al., 2007; Linscott et al., 2008). More recent radiological data of Komotar et al. could not confirm the infiltrative extension and described all PMAs in their series regardless of tumor site as well-defined masses (Komotar et al., 2008). In line with these observations the margins of most PMAs in our study were also well-circumscribed. The available literature data are concordant with respect to the mostly high signal intensity of PMA on T2-weighted images (Arslanoglu et al., 2003; Komotar et al., 2008; Linscott et al., 2008; Horger et al., 2012). Furthermore, according to a recent study, T2 signal and apparent diffusion coefficient (ADC) values tend to be higher in PMAs than in PAs, possibly reflecting more myxoid matrix content (Horger et al., 2012). All PMAs in our series appeared hyperintense on T2-weighted scans, and in the comparison of chiasmatic-hypothalamic PMAs vs. PAs the former showed visually a more homogeneous texture. This result may correlate with the observations of Horger et al. and could be related to a higher proportion of myxoid matrix in the tumor tissue. In terms of T1 signal characteristics of PMAs there are some conflicting results in the literature. While the majority of PMAs in Komotar`s study (Komotar et al., 2008) was described as T1 hyperintense lesions without evidence of hemorrhage, other papers including the initial radiological descriptions demonstrated iso- to hypointense signal to be typical for PMAs (Komotar et al., 2004b). Correspondingly, the T1 signal of PMAs was mainly hypointense relative to cortex in our series as well. 
Although PAs are known to be highly vascular (Burger et al., 2000b), intratumoral hemorrhage is rare in PAs. Interestingly, a higher incidence of hemorrhagic onset has been recently demonstrated in PAs and PMAs compared to high-grade gliomas (Shibahara et al., 2009). PMAs may more frequently show spontaneous hemorrhage evident on CT than PAs, and this feature could be a clue in the differentiation of the two tumor entities (Linscott et al., 2008). Indeed, our results are also in line with these observations, although we had limited CT data available. Notably, a recent comparative study, however, did not find hemorrhage to be a distinguishing feature (Lee et al., 2011).

In our study PMAs less frequently contained cystic components than PAs and were mainly solid. If tumor cysts were present they were small (i.e., $<1 \mathrm{~cm}$ ) and never dominant. In contrast, PAs more often showed cystic parts which occasionally predominated the tumor volume. These results further support prior data suggesting that PMAs are mainly solid tumors with less cystic compound than PAs. The other important finding of our analysis is that contrast enhancement of the solid tumor portion was more often homogeneous in PMAs than in PAs. The underlying phenomenon might be the less microcystic tumor compound not evident on morphological sequences (Rumboldt et al., 2006); however, we can only speculate about the pathological correlate of this result. The first case series reporting the radiological findings of 4 PMAs also described these tumors as homogeneously enhancing solid tumors (Arslanoglu et al., 2003). In contrast, a more recent work from Linscott et al. emphasized the heterogeneous imaging spectrum of PMAs; among others they found variable enhancement patterns including some cases (9\% of their series) with no enhancement (Linscott et al., 2008). Interestingly, we also encountered a PMA without contrast enhancement.

We corroborate previous findings indicating that neither PMAs nor PAs show restricted diffusion (Komotar et al., 2008; Horger et al., 2012). This corresponds to the low cellularity histological appearance of these tumors. Furthermore, ADC values may be suitable measures of preoperative differentiation of cerebellar pediatric tumors, especially PAs from medulloblastomas (Rumboldt et al., 2006). Interestingly, one of the PAs in our series included a solid tumor portion with restricted diffusion and corresponding hyperdensity on non-contrast CT (Appendix Figure I). Although PAs are known to have a "biphasic pattern" with alternating loose and dense areas, even the denser areas are not so cellular to cause restricted diffusion on 
MRI. Thus, our observation is unique and may represent a rare case with highly cellular tumor portion.

Tumor location, extent of resection, histological subtype, association with NF1 and age at diagnosis are influential factors for the clinical course of patients with LGG (Fernandez et al., 2003; Gnekow et al., 2012). It appears that children <1 year of age at tumor diagnosis have particularly unfavorable survival rate. PMAs are known to behave more aggressively than PAs (Mirow et al., 2014). Patients with PMA are more prone to tumor recurrence and generally have a shorter progression-free survival (Komotar et al., 2004a). Furthermore, in the early study of Komotar et al., CSF dissemination as type of tumor recurrence was only seen in very young children with PMAs but not in cases with PAs of the same tumor location. In addition, a recent paper indicated that patients with cerebellar PMA may experience higher rates of local recurrence and CSF dissemination in comparison to PAs (Forbes et al., 2011). Notably, CSF dissemination of LGGs is generally more frequent in the youngest patient population (Gnekow et al., 2012). Since patients with PMA are generally younger than those with PA, it is not completely clear whether the age at diagnosis may influence the occurrence of CSF dissemination and the at least partially related clinical outcome. In the present study we found a significantly higher rate of MRI-verified CSF dissemination in patients with suprasellar PMA than in an age- and tumor-location-matched group of children with PA. Thus, it appears that the histological evidence of PMA is indeed, independent of age, associated with higher rate of CSFdissemination.

PMA received a grade II assignment in the latest WHO classification and due to its more aggressive nature, it is considered as a distinct variant of PA. Most studies underline the histological resemblance of PMA to PA and propose a similar astrocytic origin, however, the cell origin and exact pathogenesis of the PMA are still unclear (Fuller et al., 2001; Chikai et al., 2004; Jeon et al., 2008). Growing evidence suggests that the two tumor types are pathologically and genetically related. This is supported firstly by reports of PMA recurrences as PA (Chikai et al., 2004; Ceppa et al., 2007; Kleinschmidt-DeMasters et al., 2008). This “maturation” phenomenon may represent a transformation to a more differentiated state within a single tumor spectrum, either spontaneously or potentially related to therapy. The existence of hybrid tumors with features of both PA and PMA also corroborate the idea of a tumor continuum with pure PMAs and PAs at the two ends of the spectrum (Johnson et al., 2010). Due to the limited data it 
is to date challenging to interpret these histologically mixed tumors in terms of behavior and likelihood of dissemination. In our study we presented data of eight patients with PA with focal pilomyxoid features. These tumors were located in various regions of the brain and showed a morphological heterogeneity regarding the presence of cysts or contrast enhancing pattern. In addition, the age range at tumor diagnosis was wide and CSF dissemination was observed in the youngest child only. These data indicate that this histologically mixed tumor type may occur virtually at any intracranial location and at any age typical for PAs and PMAs with various imaging appearance and, thus, they could represent a stage within the "maturation” process. Furthermore, results of a recent genome-wide gene copy number analysis provided additional argument for the "spectrum disease” thesis (Jeon et al., 2008). Interestingly, the same study reported worse survival of patients with the above mentioned mixed-form PMA/PA in comparison to classical chiasmatic-hypothalamic PAs and also observed one PMA that transferred into a PA after recurrence.

There are limited data regarding the effectiveness of therapeutic strategies for PMA. Thus, there is currently no established specific treatment protocol for PMA patients, and they are treated in a similar manner as those with PA. GTR of both tumors should always be intended since it is associated with longer progression-free survival than partial resection (Gnekow et al., 2012). However, many midline PAs and PMAs are not amenable to GTR and require adjuvant therapy. PAs have an excellent prognosis even in cases when only partial resection can be achieved, whereas PMAs are generally associated with poorer clinical course. In very young children, like in most patients with PMA, chemotherapy as an adjuvant treatment is preferred in order to avoid the deleterious side-effects of radiation therapy on the maturing brain (Goodden et al., 2014). Initial experiences with certain chemotherapy regimens [i.e., cisplatin/carboplatin and etoposid; (Tsugu et al., 2009)] applied to PMAs provided promising results and underline the importance of further research of aggressive therapy strategies often required by PMA. In addition, there are ongoing discussions regarding the question if PMA and PA patients may qualify for a novel therapeutic approach with inhibitors targeting the RAF/MAPK/ERK pathway that was found to be activated in almost all tumors (Aktas et al., 2014; Karajannis et al., 2014). 


\section{Strengths and limitations}

Knowing the rarity of PMAs our study population is considered to be one of the largest to date. Yet, apparent differences in some imaging features (like presence of large cysts vs. small cysts; see Table 1a) did not reach significance in our statistical analysis suggesting that even larger populations may be needed to precisely describe the general imaging appearance oand clinical behavior of these tumors. The relatively high case number could be achieved by collecting MRI scans from various institutes with the limitation of having different magnetic field strengths, sequence protocols and contrast agents. We believe that the visual and semi-quantitative evaluation of the imaging data was not influenced substantially by these differences. Furthermore, only scans with good image quality were included in the present study.

The group of PAs was defined according to strict criteria in order to obtain a homogeneous group for comparison. The upper age limit was set up based on the age of the oldest child with PA with pilomyxoid features. In addition, none of the patients had NF1, and only PAs with chiasma-hypothalamus localization (and without diffuse tumor extention along the optic pathway) were involved. Admittedly, this allowed us the comparison of PMAs to only a limited subset of PAs. However, as most PMAs are located in the chiasma-hypothalamus area, we could thus compare closely matched groups. This was further accomplished by carrying out a subgroup analysis matched for age and tumor location. Another major strength of our study is that the histological diagnosis of all tumors was confirmed by the Brain Tumor Reference Center of the DGNN. The present study was considered to describe radiological aspects of PMAs in comparison to PAs. This also applies to the occurrence of CSF dissemination which we could/intended to evaluate based on imaging data. We are aware of the fact that imaging is not completely sensitive and specific for meningeal tumor spread. Microscopic tumor seeding (M1 stage) cannot be identified using imaging methods, therefore our data may underestimate the occurrence of CSF dissemination. In addition, we may not have received all follow-up MRI scans of our patients. A further larger study compounding long-term follow-up clinical a radiological data, particularly of very young children is warranted to elucidate the differences between PMAs and PAs in terms of long-term clinical outcome and tumor dissemination. 


\section{Conclusions}

PMAs may exhibit imaging features, like more homogeneous texture and contrast enhancement, uncommon presence of tumor cysts or more frequent intratumoral hemorrhage that differ from those of PAs on the group level. However, unequivocal preoperative differentiation of these tumor entities in an individual case remains difficult. Our data support the earlier observations showing a higher rate of meningeal tumor spread in patients with PMA, especially in the very young patient population. Thus, in young children with a chiasmatic-hypothalamic tumor suggestive of a PMA, an intensive search for CSF dissemination along the entire neuraxis should be performed. 


\section{SUMMARY}

Background and Aims: PMA is a recently described rare tumor entity occuring most often in young children. Due the worse outcome of PMA-patients as compared to children with pilocytic astrocytoma (PA), it has received a grade II assignment in the latest WHO classification. Nevertheless, increasing evidence suggests that the two tumor types are indeed pathologically and genetically related. The radiological differentiation of PMAs from PAs is challenging and the limited available data could not yet provide unequivocal distinguishing imaging features. Furthermore, it is not completely clarified whether PMA cases are associated with a higher rate of CSF dissemination compared to similarly young patients with PA. The aim of our study was firstly to compare MR/CT imaging features of these tumors, and secondly, to evaluate the occurrence of CSF dissemination.

Material and Methods: The study population included 15 children with PMA and 32 children with PA. A third group consisted of eight children with PAs with focal pilomyxoid features. All cases had been registered in the German multicenter SIOP/HIT-LGG trials. The initial MRIs (and CT scans, if available) at establishing the diagnosis were retrospectively analyzed according to standardized criteria and the findings compared between PMAs and PAs. Furthermore, we compared the occurrence of imaging evidences of CSF tumor dissemination between children with PMA and PA, respectively.

Results: The imaging appearance of PMAs and PAs was very similar. However, PAs tended to show more frequently cystic components $(\mathrm{p}=0.03)$. As opposed to PAs, PMAs did not have large tumor cysts. We did not find differences with respect to tumor size and tumor margin. Gadolinium enhancement of PMAs was significantly more frequently homogeneous ( $\mathrm{p}=0.006$ ). PMAs appeared to show more often intratumoral hemorrhages $(\mathrm{p}=0.047)$. Furthermore, suprasellar PMAs tended to have a more homogeneus texture on T2-weighted MR images ( $\mathrm{p}=0.026$ ). Within the subgroup $<6$ years of age the PMA histology tended to have a larger effect on the occurrence of CSF dissemination than the age ( $\mathrm{p}=0.05$ vs.0.12). 
Conclusions: Although the radiological appearance of PMAs and PAs is similar, some imaging features, like enhancement pattern or presence of cysts or hemorrhage may help differentiating these low-grade gliomas. Our results corroborate previous scarce data suggesting higher rate of CSF dissemination in PMAs, even in the youngest patient population. Thus, in young children with a chiasmatic-hypothalamic tumor suggestive of a PMA, an intensive search for CSF dissemination along the entire neuraxis should be performed. 


\section{ZUSAMMENFASSUNG}

Hintergrund und Ziele: Das PMA ist eine seltene benigne Tumorentität (WHO Grad II nach der Klassifikation von 2007), welche vorwiegend bei Kleinkindern vorkommt. Dem PMA wird eine schlechtere Prognose als dem PA zugeschrieben. Die radiologische Unterscheidung zwischen PMA und PA erscheint schwierig. Zudem ist unklar inwieweit das PMA mit einer höheren Meningeoserate assoziiert sein könnte, verglichen zum PA bei Patienten vergleichbaren Alters. Das Ziel unserer Studie war es, bildgebende Kriterien sowie das Auftreten einer Liquordissemination zwischen beiden Tumorarten zu vergleichen.

Material und Methoden: Das untersuchte Kollektiv umfasste 15 Kinder mit PMA sowie 32 Kinder mit PA. Zudem eine dritte Gruppe umfasste 8 Kinder mit PA mit fokalen pilomyxoiden Merkmale. Die initialen MRT-Untersuchungen bei Diagnosestellung wurden anhand standardisierter bildgebender Kriterien analysiert. Anhand der MRT-Bildgebung wurde des Weiteren das Auftreten einer Liquordissemination bei Diagnose und im Verlauf verglichen.

Ergebnisse: PMAs und PAs stellten sich bildmorphologisch ähnlich dar. PAs zeigten öfters zystische Tumorkomponente $(\mathrm{p}=0.03)$. Im Gegensatz $\mathrm{zu}$ PAs, wiesen PMAs keine großen Tumorzysten auf. Auch die Kontrastmittelanreicherung war häufiger homogen in PMAs $(\mathrm{p}=0.006)$. Intratumorale Hämorrhagien konnten häufiger in PMAs beobachtet werden ( $\mathrm{p}=0.047$ ). Desweiteren haben sich supraselläre PMAs in der T2-Wichtung häufiger homogener dargestellt ( $\mathrm{p}=0.026)$. Die histologische Diagnose PMA schien einen größeren Effekt $(\mathrm{p}=0.05)$ auf das Auftreten einer Liquordissemination zu haben als das Alter selbst ( $\mathrm{p}=0.12)$.

Schlussfolgerungen: Obwohl sich PMA und PA in der Bildgebung sehr ähnlich darstellen, identifizierten wir einige Kriterien welche beitragen könnten diese Tumorentitäten zu unterscheiden. Bei radiomorphologischen Kriterien, die für ein PMA sprechen, sollte bei den jungen Kindern gezielt nach einer Liquordisseminierung gesucht werden. 


\section{REFERENCES}

Aktas ON, Tihan T (2014) The morphologic and molecular characteristics of pilocytic astrocytomas and the role of MAPK pathway: what does not kill you makes you stronger. Adv Anat Pathol 21:144-150.

Arslanoglu A, Cirak B, Horska A, Okoh J, Tihan T, Aronson L et al. (2003) MR imaging characteristics of pilomyxoid astrocytomas. AJNR Am J Neuroradiol 24:1906-1908.

Beckmann EC (2006) CT scanning the early days. Br J Radiol 79:5-8.

Bhargava D, Sinha P, Chumas P, Al-Tamimi Y, Shivane A, Chakrabarty A et al. (2013) Occurrence and distribution of pilomyxoid astrocytoma. Br J Neurosurg 27:413-418.

Bian SX, McAleer MF, Vats TS, Mahajan A, Grosshans DR (2013) Pilocytic astrocytoma with leptomeningeal dissemination. Childs Nerv Syst 29:441-450.

Burger PC, Scheithauer BW (2002) The brain: tumors. In: Surgical pathology of the nervous system and its coverings., 4th Edition (Burger P, Scheithauer B, eds), pp 203-215. Philadelphia: Churchill Livingstone.

Burger PC, Cohen KJ, Rosenblum MK, Tihan T (2000a) Pathology of diencephalic astrocytomas. Pediatr Neurosurg 32:214-219.

Burger PC, Scheithauer BW, Paulus W, Szymas J, Gianini C, Kleihues P (2000b) Pilocytic astrocytoma. In: Pathology and genetics of tumors of the nervous system. (Kleihues P, Cavenee W, eds), pp 45-51. Lyon, France: IARC.

Ceppa EP, Bouffet E, Griebel R, Robinson C, Tihan T (2007) The pilomyxoid astrocytoma and its relationship to pilocytic astrocytoma: report of a case and a critical review of the entity. $J$ Neurooncol 81:191-196.

Chang CH, Housepian EM, Herbert C, Jr. (1969) An operative staging system and a megavoltage radiotherapeutic technic for cerebellar medulloblastomas. Radiology 93:1351-1359.

Chikai K, Ohnishi A, Kato T, Ikeda J, Sawamura Y, Iwasaki Y et al. (2004) Clinico-pathological features of pilomyxoid astrocytoma of the optic pathway. Acta Neuropathol 108:109-114.

Cirak B, Horska A, Barker PB, Burger PC, Carson BS, Avellino AM (2005) Proton magnetic resonance spectroscopic imaging in pediatric pilomyxoid astrocytoma. Childs Nerv Syst 21:404409. 
Coakley KJ, Huston Jr, Scheithauer BW, Forbes G, Kelly PJ (1995) Pilocytic astrocytomas: well-demarcated magnetic resonance appearance despite frequent infiltration histologically. Mayo Clin Proc 70:747-751.

Cottingham SL, Boesel CP, Yates AJ (1996) Pilocytic astrocytoma in infants: A distinctive histological pattern. (abstract). J Neuropathol Exp Neurol 55:654.

Fernandez C, Figarella-Branger D, Girard N, Bouvier-Labit C, Gouvernet J, Paz Paredes A et al. (2003) Pilocytic astrocytomas in children: prognostic factors--a retrospective study of 80 cases. Neurosurgery 53:544-553; discussion 554-545.

Forbes JA, Mobley BC, O'Lynnger TM, Cooper CM, Ghiassi M, Hanif R et al. (2011) Pediatric cerebellar pilomyxoid-spectrum astrocytomas. J Neurosurg Pediatr 8:90-96.

Fuller CE, Frankel B, Smith M, Rodziewitz G, Landas SK, Caruso R et al. (2001) Suprasellar monomorphous pilomyxoid neoplasm: an ultastructural analysis. Clin Neuropathol 20:256-262.

Gajjar A, Sanford RA, Heideman R, Jenkins JJ, Walter A, Li Y et al. (1997) Low-grade astrocytoma: a decade of experience at St. Jude Children's Research Hospital. J Clin Oncol 15:2792-2799.

Gnekow AK, Falkenstein F, von Hornstein S, Zwiener I, Berkefeld S, Bison B et al. (2012) Long-term follow-up of the multicenter, multidisciplinary treatment study HIT-LGG-1996 for low-grade glioma in children and adolescents of the German Speaking Society of Pediatric Oncology and Hematology. Neuro Oncol 14:1265-1284.

Gol A, Mc Kissock W (1959) The cerebellar astrocytomas: a report on 98 verified cases. $J$ Neurosurg 16:287-296.

Golash A, Thorne J, West CG (1998) Low grade pilocytic astrocytoma presenting as a spontaneous intracerebral haemorrhage in a child. Br J Neurosurg 12:59-62.

Goodden J, Pizer B, Pettorini B, Williams D, Blair J, Didi M et al. (2014) The role of surgery in optic pathway/hypothalamic gliomas in children. $J$ Neurosurg Pediatr 13:1-12.

Gottfried ON, Fults DW, Townsend JJ, Couldwell WT (2003) Spontaneous hemorrhage associated with a pilomyxoid astrocytoma. Case report. J Neurosurg 99:416-420.

Horger M, Vogel MN, Beschorner R, Ernemann U, Worner J, Fenchel M et al. (2012) T2 and DWI in pilocytic and pilomyxoid astrocytoma with pathologic correlation. Can J Neurol Sci 39:491-498. 
Hukin J, Siffert J, Velasquez L, Zagzag D, Allen J (2002) Leptomeningeal dissemination in children with progressive low-grade neuroepithelial tumors. Neuro Oncol 4:253-260.

Igbaseimokumo U (2009) Brain CT Scans in Clinical Practice, 1st Edition. London, UK: Springer.

Janisch W, Schreiber D, Martin H, Gerlach H (1985) Diencephalic pilocytic astrocytoma with clinical onset in infancy. Biological behavior and pathomorphological findings in 11 children. Zentralbl Allg Pathol 130:31-43.

Jeon YK, Cheon JE, Kim SK, Wang KC, Cho BK, Park SH (2008) Clinicopathological features and global genomic copy number alterations of pilomyxoid astrocytoma in the hypothalamus/optic pathway: comparative analysis with pilocytic astrocytoma using array-based comparative genomic hybridization. Mod Pathol 21:1345-1356.

Johnson MW, Eberhart CG, Perry A, Tihan T, Cohen KJ, Rosenblum MK et al. (2010) Spectrum of pilomyxoid astrocytomas: intermediate pilomyxoid tumors. Am J Surg Pathol 34:1783-1791. Kalender WA (2000) Computed Tomography: Fundamentals, System Technology, Image Quality, Applications., 3rd Edition. Munich: MCD Verlag.

Karajannis MA, Legault G, Fisher MJ, Milla SS, Cohen KJ, Wisoff JH et al. (2014) Phase II study of sorafenib in children with recurrent or progressive low-grade astrocytomas. Neuro Oncol 16:1408-1416.

Khanani MF, Hawkins C, Shroff M, Dirks P, Capra M, Burger PC et al. (2006) Pilomyxoid astrocytoma in a patient with neurofibromatosis. Pediatr Blood Cancer 46:377-380.

Kleinschmidt-DeMasters BK, Foreman N, Handler M (2008) Pilomyxoid tumors with a chronic relapsing course may become more cystic and mature to pilocystic histology: abstract from the International Symposium on Pediatric Neuro-oncology. J Neurooncol:72-79.

Koeller KK, Rushing EJ (2004) From the archives of the AFIP: pilocytic astrocytoma: radiologic-pathologic correlation. Radiographics 24:1693-1708.

Komakula ST, Fenton LZ, Kleinschmidt-DeMasters BK, Foreman NK (2007) Pilomyxoid astrocytoma: neuroimaging with clinicopathologic correlates in 4 cases followed over time. $J$ Pediatr Hematol Oncol 29:465-470.

Komotar RJ, Carson BS, Rao C, Chaffee S, Goldthwaite PT, Tihan T (2005a) Pilomyxoid astrocytoma of the spinal cord: report of three cases. Neurosurgery 56:191. 
Komotar RJ, Burger PC, Carson BS, Brem H, Olivi A, Goldthwaite PT et al. (2004a) Pilocytic and pilomyxoid hypothalamic/chiasmatic astrocytomas. Neurosurgery 54:72-79; discussion 7980.

Komotar RJ, Mocco J, Jones JE, Zacharia BE, Tihan T, Feldstein NA et al. (2005b) Pilomyxoid astrocytoma: diagnosis, prognosis, and management. Neurosurg Focus 18:E7.

Komotar RJ, Mocco J, Zacharia BE, Wilson DA, Kim PY, Canoll PD et al. (2006) Astrocytoma with pilomyxoid features presenting in an adult. Neuropathology 26:89-93.

Komotar RJ, Mocco J, Carson BS, Sughrue ME, Zacharia BE, Sisti AC et al. (2004b) Pilomyxoid astrocytoma: a review. MedGenMed 6:42.

Komotar RJ, Zacharia BE, Sughrue ME, Mocco J, Carson BS, Tihan T et al. (2008) Magnetic resonance imaging characteristics of pilomyxoid astrocytoma. Neurol Res 30:945-951.

Lee IH, Kim JH, Suh YL, Eo H, Shin HJ, Yoo SY et al. (2011) Imaging characteristics of pilomyxoid astrocytomas in comparison with pilocytic astrocytomas. Eur J Radiol 79:311-316.

Lee YY, Van Tassel P, Bruner JM, Moser RP, Share JC (1989) Juvenile pilocytic astrocytomas: CT and MR characteristics. AJR Am J Roentgenol 152:1263-1270.

Linscott LL, Osborn AG, Blaser S, Castillo M, Hewlett RH, Wieselthaler N et al. (2008) Pilomyxoid astrocytoma: expanding the imaging spectrum. AJNR Am J Neuroradiol 29:18611866.

Listernick R, Louis DN, Packer RJ, Gutmann DH (1997) Optic pathway gliomas in children with neurofibromatosis 1: consensus statement from the NF1 Optic Pathway Glioma Task Force. Ann Neurol 41:143-149.

Louis DN, Ohgaki H, Wiestler OD, Cavenee WK, Burger PC, Jouvet A et al. (2007) The 2007 WHO classification of tumours of the central nervous system. Acta Neuropathol 114:97-109.

Mamelak AN, Prados MD, Obana WG, Cogen PH, Edwards MS (1994) Treatment options and prognosis for multicentric juvenile pilocytic astrocytoma. J Neurosurg 81:24-30.

McCowage G, Tien R, McLendon R, Felsberg G, Fuchs H, Graham ML et al. (1996) Successful treatment of childhood pilocytic astrocytomas metastatic to the leptomeninges with high-dose cyclophosphamide. Med Pediatr Oncol 27:32-39.

Mendiratta-Lala M, Kader Ellika S, Gutierrez JA, Patel SC, Jain R (2007) Spinal cord pilomyxoid astrocytoma: an unusual tumor. $J$ Neuroimaging 17:371-374. 
Merchant TE, Conklin HM, Wu S, Lustig RH, Xiong X (2009) Late effects of conformal radiation therapy for pediatric patients with low-grade glioma: prospective evaluation of cognitive, endocrine, and hearing deficits. J Clin Oncol 27:3691-3697.

Mirow C, Pietsch T, Berkefeld S, Kwiecien R, Warmuth-Metz M, Falkenstein F et al. (2014) Children $<1$ year show an inferior outcome when treated according to the traditional LGG treatment strategy: a report from the German multicenter trial HIT-LGG 1996 for children with low grade glioma (LGG). Pediatr Blood Cancer 61:457-463.

Morales H, Kwock L, Castillo M (2007) Magnetic resonance imaging and spectroscopy of pilomyxoid astrocytomas: case reports and comparison with pilocytic astrocytomas. J Comput Assist Tomogr 31:682-687.

Mulvihill JJ, Parry DM, Sherman JL, Pikus A, Kaiser-Kupfer MI, Eldridge R (1990) NIH conference. Neurofibromatosis 1 (Recklinghausen disease) and neurofibromatosis 2 (bilateral acoustic neurofibromatosis). An update. Ann Intern Med 113:39-52.

Oransky I (2004) Sir Godfrey N. Hounsfield. Lancet 364:1032.

Packer RJ, Bilaniuk LT, Cohen BH, Braffman BH, Obringer AC, Zimmerman RA et al. (1988) Intracranial visual pathway gliomas in children with neurofibromatosis. Neurofibromatosis 1:212-222.

Pencalet P, Maixner W, Sainte-Rose C, Lellouch-Tubiana A, Cinalli G, Zerah M et al. (1999) Benign cerebellar astrocytomas in children. J Neurosurg 90:265-273.

Phi JH, Lee J, Wang KC, Cho BK, Kim IO, Park CK et al. (2011) Cerebrospinal fluid M staging for medulloblastoma: reappraisal of Chang's M staging based on the CSF flow. Neuro Oncol 13:334-344.

Poretti A, Meoded A, Huisman TA (2012) Neuroimaging of pediatric posterior fossa tumors including review of the literature. J Magn Reson Imaging 35:32-47.

Porto L, Jurcoane A, Schwabe D, Kieslich M, Hattingen E (2013) Differentiation between high and low grade tumours in paediatric patients by using apparent diffusion coefficients. Eur $J$ Paediatr Neurol 17:302-307.

Poussaint TY, Barnes PD, Nichols K, Anthony DC, Cohen L, Tarbell NJ et al. (1997) Diencephalic syndrome: clinical features and imaging findings. AJNR Am J Neuroradiol 18:1499-1505. 
Rodriguez FJ, Perry A, Gutmann DH, O'Neill BP, Leonard J, Bryant S et al. (2008) Gliomas in neurofibromatosis type 1: a clinicopathologic study of 100 patients. J Neuropathol Exp Neurol 67:240-249.

Rodriguez LA, Edwards MS, Levin VA (1990) Management of hypothalamic gliomas in children: an analysis of 33 cases. Neurosurgery 26:242-246; discussion 246-247.

Rumboldt Z, Camacho DL, Lake D, Welsh CT, Castillo M (2006) Apparent diffusion coefficients for differentiation of cerebellar tumors in children. AJNR Am J Neuroradiol 27:1362-1369.

Russel A (1951) A diencephalic syndrome of emaciation in infancy and childhood. Arch Dis Child 26:274.

Shibahara I, Kanamori M, Kumabe T, Endo H, Sonoda Y, Ogawa Y et al. (2009) Hemorrhagic onset of pilocytic astrocytoma and pilomyxoid astrocytoma. Brain Tumor Pathol 26:1-5.

Tihan T, Burger PC (1998) A variant of pilocytic astrocytoma: A possible distinct clinicopathological entity with a less favorable outcome. (abstract). J Neuropathol Exp Neurol 57:500.

Tihan T, Fisher PG, Kepner JL, Godfraind C, McComb RD, Goldthwaite PT et al. (1999) Pediatric astrocytomas with monomorphous pilomyxoid features and a less favorable outcome. $J$ Neuropathol Exp Neurol 58:1061-1068.

Tsugu H, Oshiro S, Yanai F, Komatsu F, Abe H, Fukushima T et al. (2009) Management of pilomyxoid astrocytomas: our experience. Anticancer Res 29:919-926.

Udvarhelyi GB (1966) "Anorexia nervosa" caused by a fourth ventricle tumor. Neurology 16:565-568.

Wagnerova D, Herynek V, Malucelli A, Dezortova M, Vymazal J, Urgosik D et al. (2012) Quantitative MR imaging and spectroscopy of brain tumours: a step forward? Eur Radiol 22:2307-2318.

Wallner KE, Gonzales MF, Edwards MS, Wara WM, Sheline GE (1988) Treatment results of juvenile pilocytic astrocytoma. J Neurosurg 69:171-176.

Westbrook C (2008) Handbook of MRI Technique, 3rd Edition: Wiley-Blackwell.

Williams VC, Lucas J, Babcock MA, Gutmann DH, Korf B, Maria BL (2009) Neurofibromatosis type 1 revisited. Pediatrics 123:124-133. 
8. APPENDIX (representative MRI and CT images of PMAs and PAs as well as typical histological appearance of a PMA)

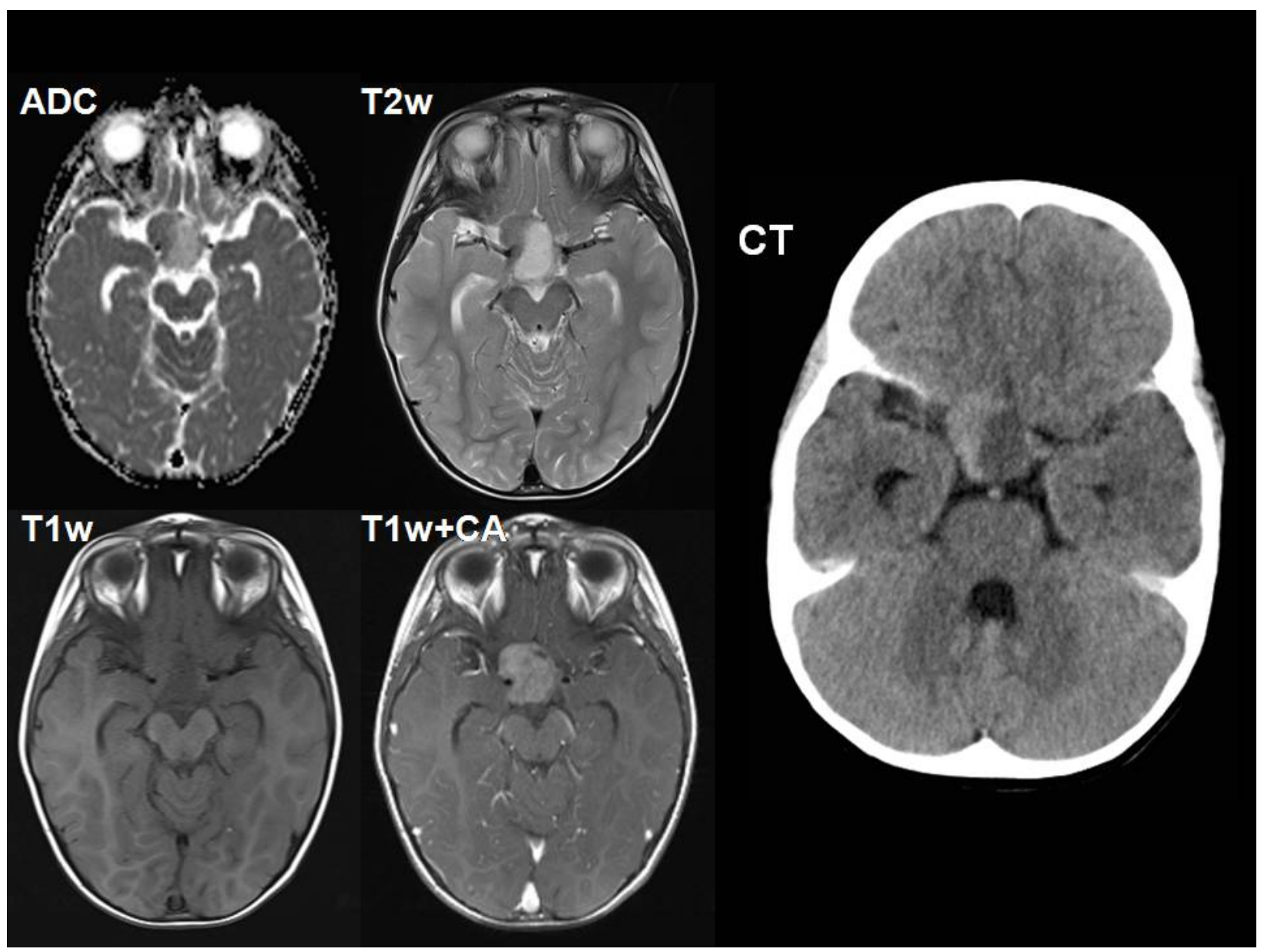

Figure I: MRI and CT images of a 2.5-year old boy with a suprasellar PA.

In this special case, parts of the solid tumor appeared hyperdense on CT and showed a corresponding diffusion restriction as a sign of high cellularity. Accordingly, T2 signal is inhomogeneous: partially hyperintense, partially hypointense. The tumor border is sharp and the contrast enhancement is moderate. 


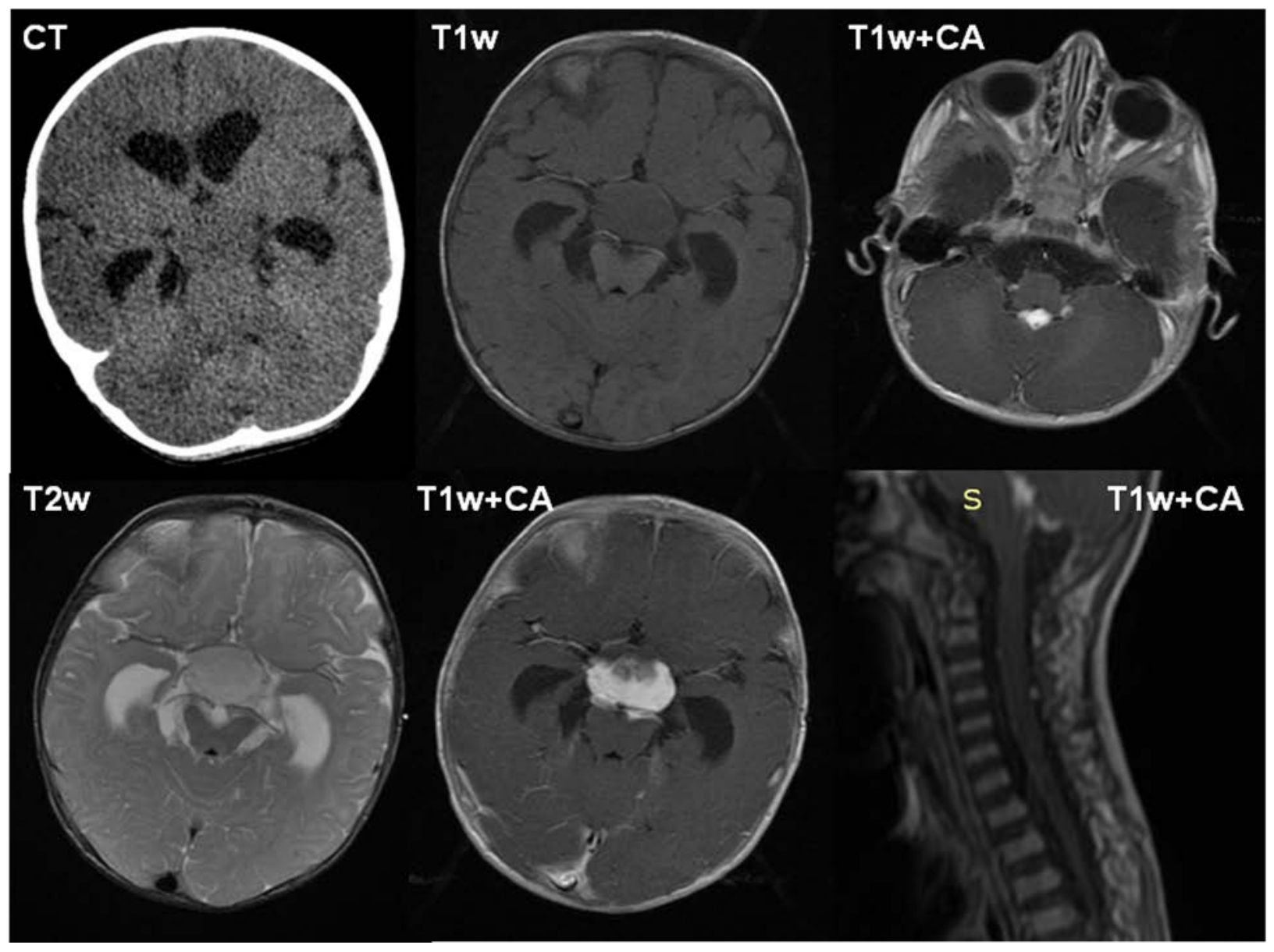

Figure II: MRI and CT images of a 6 months old infant with a suprasellar PMA.

The tumor shows hypoattenuation on CT scan compared to cerebral cortex. There is no evidence of tumor calcification or hemorrhage. Note the homogeneous hypointense signal of the lesion on non-contrast T1-weighted MRI sequence and the homogenous hyperintense texture on the T2weighted image. Approximately 50-75\% of the solid tumor enhances gadolinium and the enhancement appears intense. CSF dissemination in the fourth ventricle and along the spinal cord was evident at the time of the primary diagnostic. 


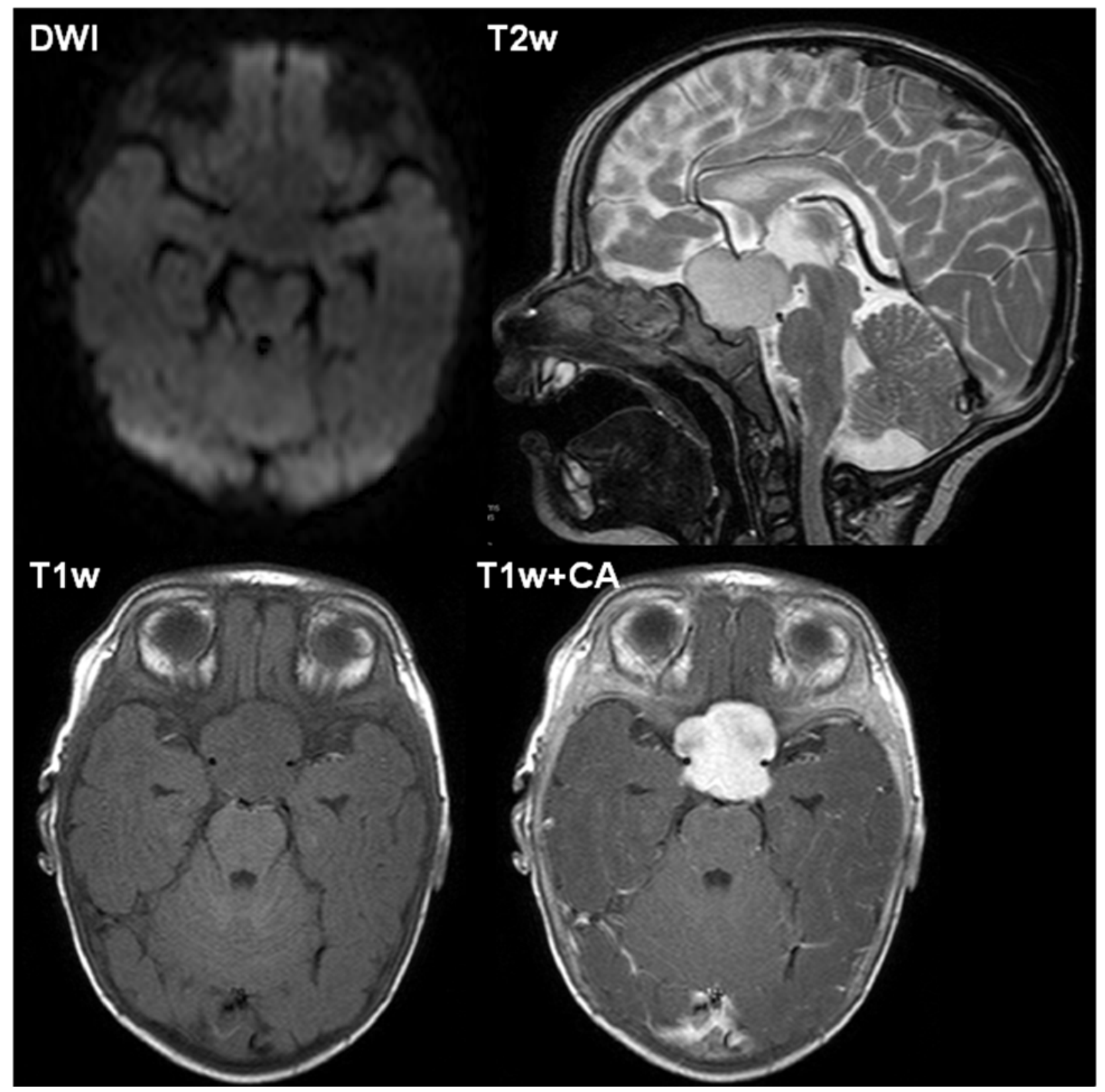

Figure III: Representative MRI images of a 3 months old infant with a suprasellar PMA.

The tumor margins are well-defined. There is no detectable tumor cyst. Note the predominantly homogeneous hyperintense T2 signal and the T1 hypointense nature of the tumor mass. The DWI sequence shows no hyperintense signal, thus there is no sign of restricted diffusion. Obviously approximately $75-100 \%$ of the tumor enhances gadolinium and the enhancement intensity is marked. 


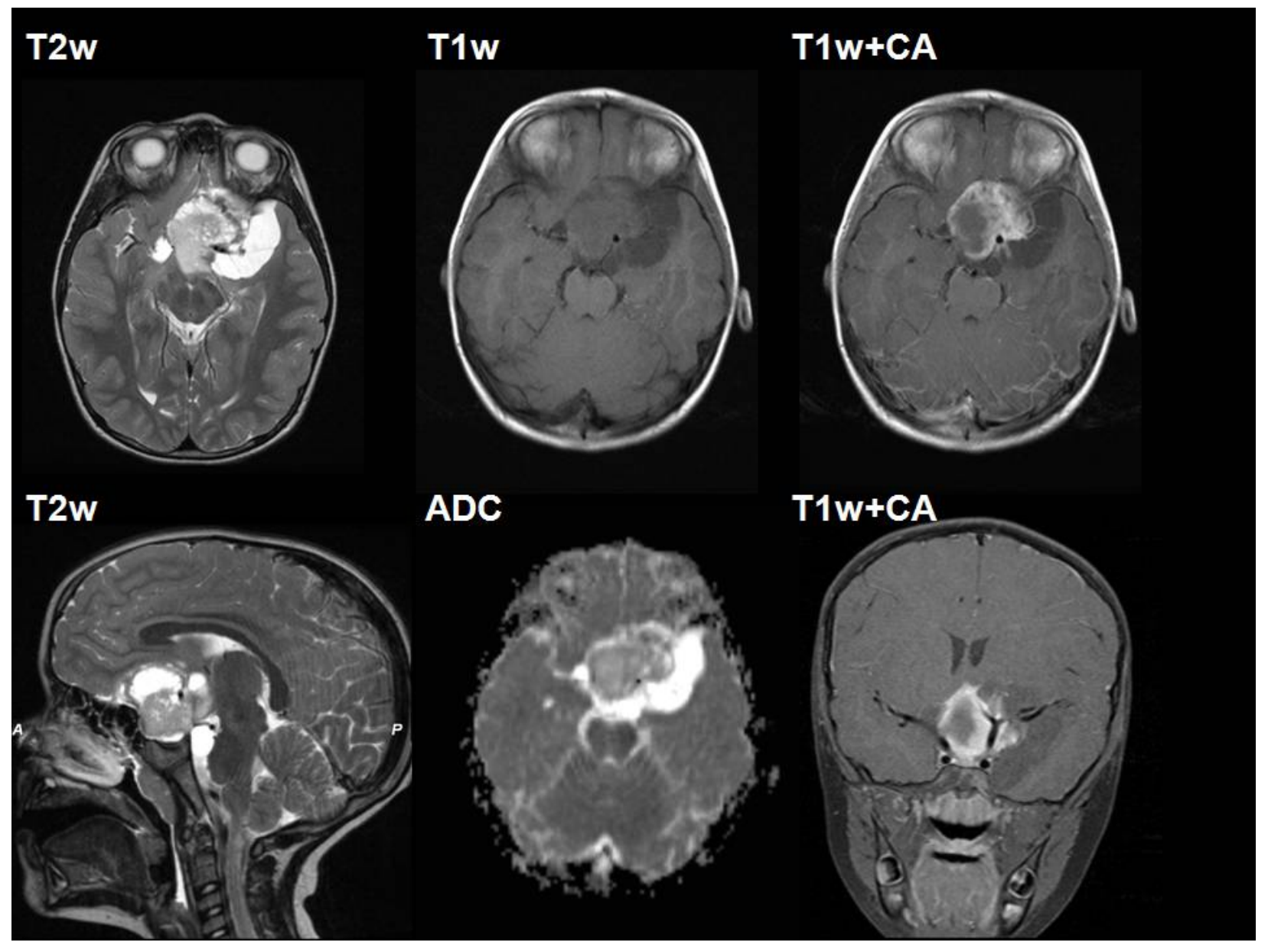

Figure IV: Representative MRI images of a 6-year old boy with a suprasellar PA.

The well-defined tumor is partially cystic; the cystic components are, however, not dominant. The solid tumor mass appears inhomogeneously hyperintense on T2-weighted scans and shows no signs of restricted diffusion (no hypointense signal on the ADC map). The contrast enhancement is inhomogeneous and intense. There are no signs of peritumoral edema or hydrocephalus. 


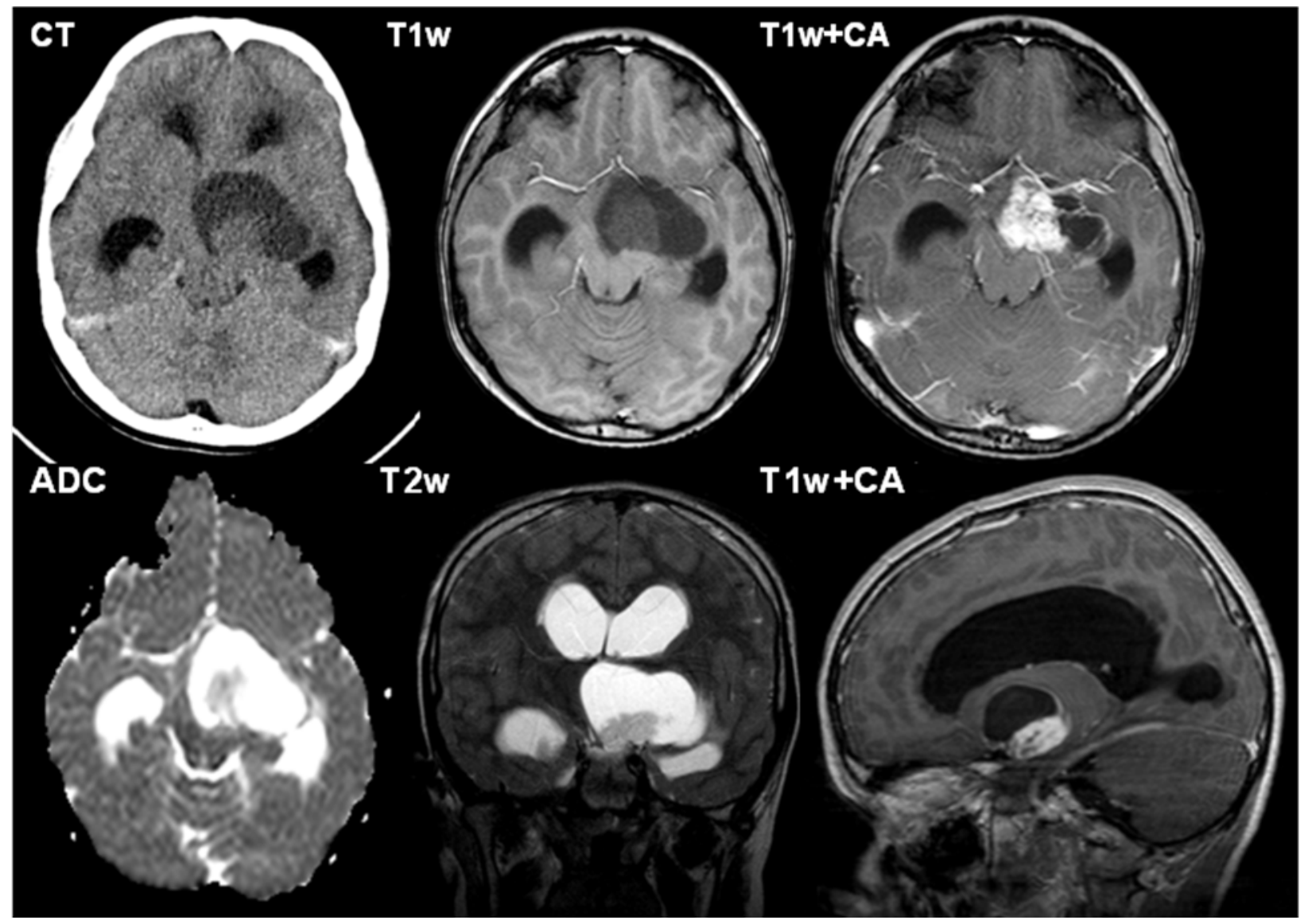

Figure V: Representative MRI and CT images of a 10.5-year old boy with a suprasellar PA with pilomyxoid features.

Note the large cystic component of the midline tumor. The solid tumor portion appears slightly hypodense on the CT scan. The texture of the solid tumor mass is inhomogeneous and shows hyperintense signal on T2-, and hypointense signal on T1-weighted sequences. There are no signs of hypercellularity i.e., no diffusion restriction on the ADC map. The contrast enhancement of the solid tumor portion is intense and inhomogeneous, note the rim enhancement of the tumor cyst. The marked obstructive hydrocephalus, caused by the tumor, can also be appreciated. 
Hematoxylin and eosin

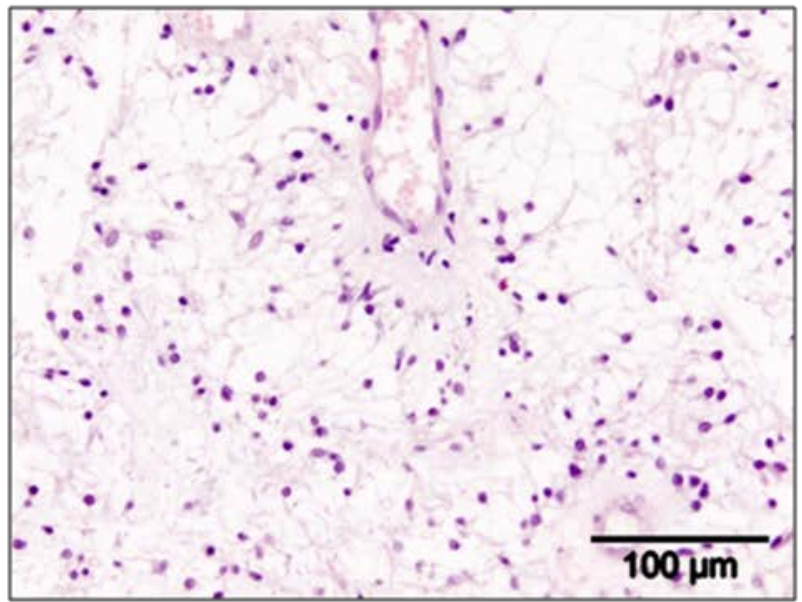

Ki-67

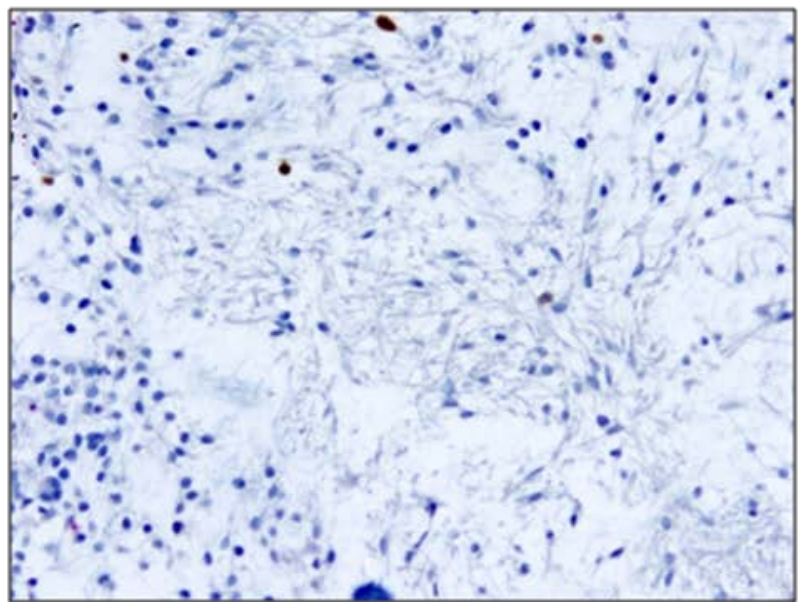

Glial fibrillary acidic protein (GFAP)

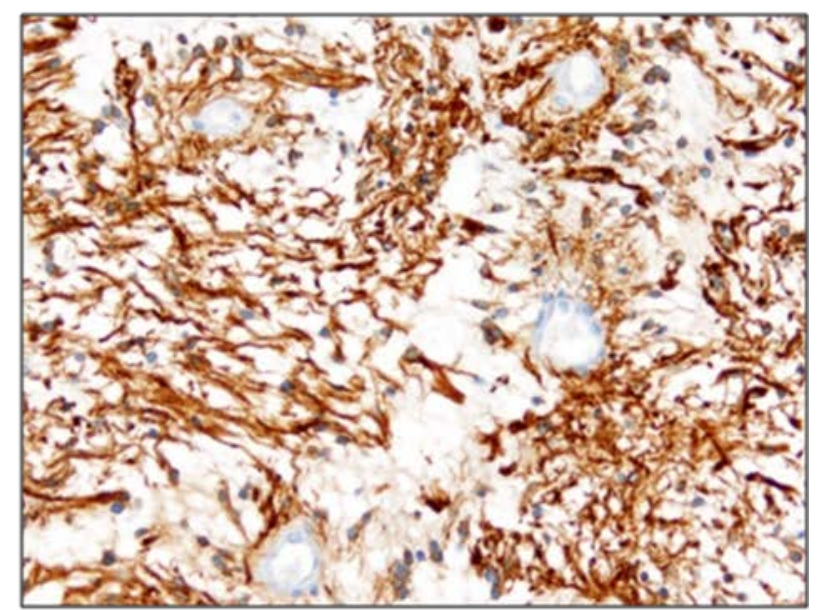

Alcian blue and PAS

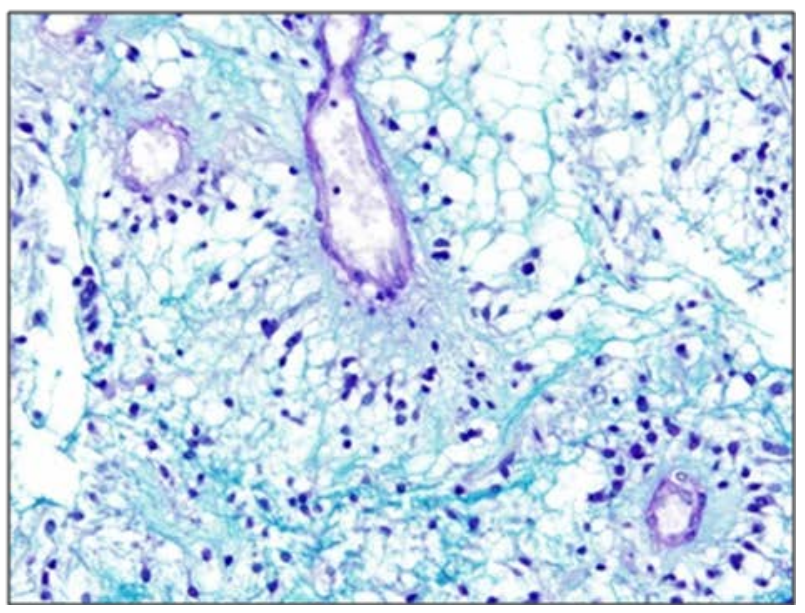

Figure VI: Histological appearance of a typical PMA. Representative histological images of a 5.7-year old boy with a suprasellar PMA (original magnification, X20). Hematoxylin and eosin, glial fibrillary acidic protein (GFAP), Ki-67 and alcian blue / PAS stainings, respectively. The tumor is composed of small monomorphous bipolar astrocytic cells with condensed chromatin and wispy cytoplasm. Note the rich myxoid background and the increased cell density around vessels (angiocentric pattern). 


\section{ABBREVIATIONS (in alphabetical order)}

ADC: apparent diffusion coefficient

CNS: central nervous system

CSF: cerebrospinal fluid

CT: computed tomography

DGNN: Deutsche Gesellschaft für Neuropathologie und Neuroanatomie

DTI: diffusion tensor imaging

DWI: diffusion weighted imaging

EPI: echo planar images

GFAP: glial fibrillary acidic protein

GTR: gross total resection

HIT: Hirntumor

LGG: low grade glioma

MRI: magnetic resonance imaging

MRS: magnetic resonance spectroscopy 
NF: neurofibromatosis

PA: pilocytic astrocytoma

PMA: pilomyxoid astrocytoma

$\mathrm{RF}$ : radiofrequency

SIOP: Société Internationale D`Oncologie Pédiatrique

TE: echo time

TR: repetition time

WHO: World Health Organization 


\section{DANKSAGUNG}

Mein besonderer Dank gilt Frau Prof. Dr. Monika Warmuth-Metz für die Möglichkeit an diesem interessanten Thema forschen zu dürfen. Ferner bedanke ich mich für ihre persönliche Betreuung und die lebendigen Diskussionen, welche die zielorientierte und erfolgreiche Weiterentwicklung meiner Dissertationsthema ermöglicht haben.

Herrn Prof. Csaba Juhász und Herrn Prof. Harry T. Chugani (Translational Imaging Laboratory, Detroit, USA) möchte ich für ihre Unterstützung und Begeisterungsfähigkeit danken, womit sie zum ersten Mal mein Interesse im Gebiet Neuroradiologie bzw. moderne bildgebende Verfahren geweckt haben.

Außerdem danke ich Herrn Prof. László Solymosi herzlich für die Geduld und Hilfe im

beruflichen Alltag, insbesondere für die angenehme Abteilungsatmosphäre und die Unterstützung meiner Facharztweiterbildung. 


\section{LEBENSLAUF}

\section{Persönliche Daten:}

Name, Vorname: Alkonyi, Bálint

Geschlecht: Männlich

Geburtsdatum: 08.04.1982

Geburtsort: Pécs, Ungarn

Nationalität: ungarisch

Familienstand: verheiratet

\section{Universitätsstudium:}

2000-2006: Medizinische Fakultät, Universität Pécs, Ungarn

Approbation (cum laude): Allgemeiner Arzt (Dr. med. Univ Pécs) seit dem 1. Juli 2006.

\section{Wissenschaftlicher Grad:}

PhD Doktorstufe seit dem 7. Februar 2012

\section{Sprachkentnisse:}

Ungarisch: Muttersprache

Deutsch: fließend (Stufe B2)

Englisch: fließend (Stufe B2)

\section{Stipendien und wissenschaftliche Projekte während des Universitätsstudiums:}

2003-2006: Wissentschaftliche Mitarbeit an der I. Klinik für Innere Medizin, Abteilung für Kardiologie, Universität Pécs, Ungarn. Thema: Azetyl-salizyilat Resistenz.

2005: Auslandsfamulatur im Robert Bosch Krankenhaus, Stuttgart -3 Monate (Innere Medizin und Chirurgie)

2003: Auslandsfamulatur an der Klinik für Innere Medizin in Wroclaw (Polen) -1 Monat

\section{Berufstätigkeit:}

Von Juli 2013 bis jetzt: Assistenzarzt (i. R. der Weiterbildungsrotation) im Institut für diagnostische und interventionelle Radiologie, Universitätsklinikum Würzburg, Deutschland, Prof. Th. Bley 
Von August 2011 bis Juni 2013: Assistenzarzt in der Abteilung für Neuroradiologie, Universitätsklinikum Würzburg, Deutschland, Prof. L. Solymosi

Von Januar 2009 bis Mai 2011: Wissenschaftlicher Mitarbeiter (Postdoc) im Translational Imaging Laboratory, Wayne State University, Detroit, MI, USA, Prof. HT Chugani, Dr. C Juhász

Von September 2006 bis November 2008: Assistenzarzt im Rahmen der Weiterbildung in Neurologie:

-1 Jahr Neurologie in der Klinik für Neurologie, Universität Pécs, Ungarn, Prof. S. Komoly -8 Monaten Innere Medizin in der III. Klinik für Innere Medizin, Universität Pécs -4 Monaten Intensivmedizin und Notfallambulanz, Universität Pécs

\section{Wissenschaftliche Interessen:}

Wissenschaftliche Untersuchung des Gehirns in verschiedenen neurologischen Krankheiten mit modernen bildgebenden Methoden. Spezieller Schwerpunkt auf Hirntumoren, Sturge-Weber Syndrom und Epilepsie.

\section{Internationale Publikationen:}

1. Nowak J, Seidel C, Pietsch T, Alkonyi B, Fuss TL, Friedrich C, von Hoff K, Rutkowski S: Systematic comparison of MRI findings in pediatric ependymoblastoma with ependymoma and CNS primitive neuroectodermal tumor not otherwise specified. Neuro Oncol. 2015 Aug;17(8):1157-65.

2. Alkonyi B, Nowak J, Gnekow AK, Pietsch T, Warmuth-Metz M: Differential imaging characteristics and dissemination potential of pilomyxoid astrocytomas versus pilocytic astrocytomas. Neuroradiology. 2015 Jun;57(6):625-38.

3. Schraven S, Mlynski R, Dahlhoff E, Alkonyi B, Gummer AW, Hagen R: Vibro-EAS: a proposal for advanced electroacoustic stimulation. Otol Neurotol. 2015 Jan;36(1):22-7.

4. Alkonyi B, Günthner-Lengsfeld T, Rak K, Solymosi L and Hagen R: An endolymphatic sac tumor with imaging features of aneurysmal bone cysts: Differential diagnostic considerations. Childs Nerv Syst. 2014 Sep;30(9):1583-8. 
5. Nowak J, Alkonyi B, Rutkowski S, Homola GA, Warmuth-Metz M: Hypertrophic olivary degeneration with gadolinium enhancement after posterior fossa surgery in a child with medulloblastoma. Childs Nerv Syst. 2014 May;30(5):959-62.

6. Alkonyi B, Barger GR, Mittal S, Muzik O, Chugani DC, Bahl G, Robinette NL, Kupsky WJ, Chakraborty PK and Juhasz C: Accurate differentiation of recurrent gliomas from radiation injury by kinetic analysis of alpha- $\left[{ }^{11}\right.$ C]methyl-L-tryptophan PET. J Nucl Med. 2012 Jul;53(7):1058-64.

7. Alkonyi B, Miao Y, Wu J, Cai Z, Hu J, Chugani HT and Juhász C: A perfusion-metabolic mismatch in Sturge-Weber syndrome: A multimodality imaging study. Brain Dev. 2012 Aug;34(7):553-62.

8. Alkonyi B, Mittal S, Zitron I, Chugani DC, Kupsky WJ, Muzik O, Chugani HT, Sood S and Juhász C: Increased tryptophan transport in epileptogenic dysembryoplastic neuroepithelial tumors. J Neurooncol. 2012 Apr;107(2):365-72.

9. Alkonyi B, Chugani HT and Juhász C: Transient focal cortical increase of interictal glucose metabolism in Sturge-Weber syndrome: Implications for epileptogenesis. Epilepsia. 2011 Jul;52(7):1265-72.

10. Alkonyi B, Chugani HT, Karia S, Behen ME and Juhász C: Clinical outcome in bilateral Sturge-Weber syndrome. Pediatric Neurology. 2011 Jun;44(6):443-9.

11. Alkonyi B, Juhasz C,, Muzik O, Behen ME, Jeong JW and Chugani HT: Thalamocortical connectivity in healthy children: asymmetries and robust developmental changes between age 8 and 17. AJNR Am J Neuroradiol 2011 May;32(5):962-9.

12. Alkonyi B, Chugani HT, Muzik O, Chugani DC, Sundaram SK, Kupsky WJ, Batista CE and Juhasz C: Increased L-[1-11C]leucine uptake in the leptomeningeal angioma of Sturge-Weber syndrome: a PET study. J Neuroimaging 2012 Apr;22(2):177-83.

13. Alkonyi B, Govindan RM, Chugani HT, Behen ME, Jeong J and Juhasz C: Focal white matter abnormalities related to neurocognitive dysfunction: An objective diffusion tensor imaging study of children with Sturge-Weber syndrome. Pediatric Res. 2011 Jan;69(1):74-9.

14. Alkonyi B, Chugani HT, Behen ME, Halverson S, Helder E, Makki MI and Juhasz C: The role of the thalamus in neuro-cognitive dysfunction in early unilateral hemispheric injury: A multimodality imaging study of children with Sturge-Weber syndrome. Eur J Paediatr Neurol. 2010 Sep;14(5):425-33. 
15. Alkonyi B, Juhász C, Muzik O, Asano E, Saporta A, Shah A, Chugani HT:

Quantitative brain surface mapping of an electrophysiologic/metabolic mismatch in human neocortical epilepsy. Epilepsy Res. 2009 Nov; 87(1):77-87.

16. Trauninger A, Alkonyi B, Kovács N, Komoly S, Pfund Z: Methylprednisolone therapy for short-term prevention of SUNCT syndrome. Cephalalgia. 2010 Jun;30(6):735-9.

17. Auer T, Janszky J, Schwarcz A, Dóczi T, Trauninger A, Alkonyi B, Komoly S, Pfund Z: Attack-related brainstem activation in a patient with SUNCT syndrome: an ictal fMRI study. Headache. 2009 Jun; 49(6): 909-12.

18. Feher G, Koltai K, Alkonyi B, Papp E, Keszthelyi Z, Kesmarky G, Toth K: Clopidogrel resistance: Role of body mass and concomitant medications. Int J Cardiol. 2007 Aug 21; 120(2): 188-92.

19. Feher G, Koltai K, Papp E, Alkonyi B, Solyom A, Kenyeres P, Kesmarky G, Czopf L, Toth $\mathrm{K}$ : Aspirin resistance: possible roles of cardiovascular risk factors, previous disease history, concomitant medications and haemorrheological variables. Drugs Aging. 2006;23(7):559-67.

\section{Buchkapitel:}

Csaba Juhász, Bálint Alkonyi and Harry T. Chugani: Imaging brain structure and function in Sturge-Weber syndrome. In: Roach ES, Bodensteiner JB. eds.: Sturge-Weber syndrome. (The Sturge-Weber Foundation, NJ, 2010)

\section{Vorträge und Poster (erster Autor wenn nicht anders bezeichnet):}

1. Pilomyxoides Astrozytom und pilozytisches Astrozytom: Vergleich anhand der Bildgebung [Vortag] (49. Kongress der Deutschen Gesellschaft für Neuroradiologie, Köln, Oktober, 2014)

2. Neuroradiology of the temporal bone [Vortrag] (26th Course on microsurgery of the middle ear, Würzburg, February, 2014)

3. Tumor induction by CT: Bias or matter of fact - can or should we perform CI without CT? [Vortag] (11th Wullstein Symposium, Würzburg, February, 2014)

4. Neuroradiology of the temporal bone [Vortrag] (25th Course on microsurgery of the middle ear, Würzburg, February, 2013) 
5. Juhász C, Alkonyi B, Hu J, Xuan Y, Chugani HT: Neurometabolic abnormalities and epileptogenesis in Sturge-Weber syndrome [Poster]

(2011 Child Neurology Society Annual Meeting, Providence, RI, USA, October, 2011)

6. Differentiation of recurrent gliomas from radiation necrosis by kinetic analysis of $\alpha$ $\left[{ }^{11}\right.$ C]methyl-L-tryptophan PET [Vortrag]

(2011 Annual Meeting of the American Academy of Neurology, Honolulu, HI, USA, April, 2011)

7. White matter perfusion abnormalities in Sturge-Weber syndrome: Relation to cortical glucose metabolism and seizure severity [Poster]

(2011 Annual Meeting of the American Academy of Neurology, Honolulu, HI, USA, April, 2011)

8. Metabolic and molecular imaging characteristics of epileptogenic dysembryoplastic neuroepithelial tumors (DNETs) [Poster]

(2010 Annual Meeting of The American Epilepsy Society, San Antonio, TX, USA, December, 2010)

9. Mittal S, Zitron IM, Kupsky WJ, Alkonyi B, Sood S, Juhasz C: Cytokine-mediated inflammation in epileptogenic dysembryoplastic neuroepithelial tumors [Poster] (The 15th Annual Scientific Meeting of the Society for Neuro-Oncology, Montreal, Canada, November, 2010)

10. Focal white matter diffusion abnormalities in children with Sturge-Weber syndrome:

Relation to neurocognitive dysfunction [Poster]

(Child Neurology Society $39^{\text {th }}$ Annual Meeting, Providence, RI, USA, October, 2010)

11. Muzik O, Pai D, Alkonyi B, Juhász C, Hua J: Performance evaluation of an integrative software environment for analysis of multi-modality neuroimaging data [Vortrag]

(SNM 57th Annual Meeting, Salt Lake City, Utah, USA, June, 2010.)

12. Increased L-[1-11C]leucine Uptake in the Angioma Associated with Cortical Hypometabolism in Children with Sturge-Weber Syndrome: a PET Study [Poster] (Molecular Neuroimaging Symposium, National Institutes of Health, Bethesda, Maryland, USA, May, 2010)

Image of the month (July 2010 in SNM Molecular Imaging Center of Excellence website) reprinted from J Nucl Med. 2010;51:827,830. 
13. Focal cerebral increases of $\alpha$-[11C]methyl-L-tryptophan (AMT) uptake suggest activation of the kynurenine pathway in multiple sclerosis: a PET study [Poster] (2010 Annual Meeting of the American Academy of Neurology, Toronto, Canada, April, 2010)

14. Metabolic and diffusion abnormalities of the thalamus and their cognitive correlates in unilateral Sturge-Weber syndrome [Poster]

(2010 Annual Meeeting of the American Academy of Neurology, Toronto, Canada, April, 2010)

15. Quantitative brain surface mapping of cortical hypometabolism in neocortical epilepsy [Poster]

(2009 Annual Meeting of the American Epilepsy Society, Boston, MA, USA, December, 2009)

16. Ergänzende MR bildgebende Vorfahren in Kopfschmerzen mit der Abstammung von dem trigeminal Nerv [Vortrag]

(Conference of the Hungarian Society of Headache, Siófok, Hungary, 2008)

17. Eine iktale fMRI Studie eines Patientes mit SUNCT Syndrome [Vortrag]

(Conference of the Hungarian Society of Headache, Siófok, Hungary, 2007)

\section{Publizierte Abstracts:}

1. Bálint Alkonyi, Geoffrey R. Barger, Sandeep Mittal, Otto Muzik, Gautam Bahl, Pulak K. Chakraborty and Csaba Juhasz: Differentiation of recurrent gliomas from radiation necrosis by kinetic analysis of $\alpha$-[11C]methyl-L-tryptophan PET. Neurology 2011;76 (Suppl 4) A182.

2. Bálint Alkonyi, Yanwei Miao, Jiani Hu, Harry T. Chugani and Csaba Juhasz: White matter perfusion abnormalities in Sturge-Weber syndrome: Relation to cortical glucose metabolism and seizure severity. Neurology 2011;76 (Suppl 4) A301.

3. Sandeep Mittal, Ian M. Zitron, William J. Kupsky, Bálint Alkonyi, Sandeep Sood and Csaba Juhász: Cytokine-mediated inflammation in epileptogenic dysembryoplastic neuroepithelial tumors. Neuro-Oncology 2010;12 (suppl 4): iv32.

4. Bálint Alkonyi, Rajkumar M. Govindan, Harry T. Chugani, Michael E. Behen, Jeong-Won Jeong, Csaba Juhász: Focal White Matter Diffusion Abnormalities in Children with SturgeWeber Syndrome: Relation to Neurocognitive Dysfunction. Ann Neurol 2010;68 (suppl 14):DD5 . 
5. Otto Muzik, Darshan Pai, Bálint Alkonyi, Csaba Juhász, Jing Hua: Performance evaluation of an integrative software environment for analysis of multi-modality neuroimaging data. $\mathrm{J} \mathrm{NuCl}$ Med. 2010; 51 (Suppl 2) 82P.

6. Bálint Alkonyi, Harry T. Chugani, Otto Muzik, Diane C. Chugani, Senthil K. Sundaram, William J. Kupsky, Carlos Batista and Csaba Juhász: Increased L-[1-11C]leucine Uptake in the Angioma Associated with Cortical Hypometabolism in Children with Sturge-Weber Syndrome: a PET Study. J Nucl Med. 2010;51:827.

7. Bálint Alkonyi, James Y. Garbern, Diane C. Chugani, Otto Muzik, Pulak Chakraborty and Csaba Juhász:

Focal cerebral increases of $\alpha$-[11C]methyl-L-tryptophan uptake suggest activation of the kynurenine pathway in multiple sclerosis: a PET study. Neurology 74 March 2, 2010 (Suppl 2) A238.

8. Bálint Alkonyi, Harry T. Chugani, Michael E. Behen, Stacey Halverson, Emily Helder, Malek I. Makki and Csaba Juhász:

Metabolic and diffusion abnormalities of the thalamus and their cognitive correlates in unilateral Sturge-Weber syndrome.

Neurology 74 March 2, 2010 (Suppl 2) A230.

9. Bálint Alkonyi, C. Juhasz, O. Muzik, E. Asano, A. Saporta, A. Shah and H. T. Chugani: Quantitatvive brain surface mapping of cortical hypometabolism in neocortical epilepsy. Epilepsia 50 Nov, 2009 (Suppl 11) pp. 427-428.

\section{Erfahrung mit EDV:}

Ausgezeichnete Kenntnisse mit Auswertungsprogrammen für MRI und PET Daten als auch mit MS Windows und MS Office.

Würzburg, den 15.07.2015 